\title{
Assessment of Elementary Mathematics Teachers' Probability Content Knowledge in terms of Different Meanings of Probability *
}

\author{
Gamze Kurt $^{\mathrm{a}}$ and Orkun Coșkuntuncel ${ }^{\mathrm{b}}$ \\ ${ }^{a}$ Mersin University, Education Faculty, Mersin/Turkey (ORCID: 0000-0002-4976-5069) \\ ${ }^{\mathbf{b}}$ Mersin University, Education Faculty, Mersin/Turkey (ORCID: 0000-0001-7251-4607)
}

Article History: Received: 28 April 2020; Accepted: 31 October 2020; Published online: 8 December 2020

\begin{abstract}
Although the international interest in teaching probability has allowed probability to be treated as a separate learning area in Turkey, its intensity has been reduced and mitigated in the middle school mathematics program. Despite this, the addition of statistics and probability courses for middle school mathematics teacher candidates during their undergraduate education shows the need for them to be trained in these subjects' teaching. However, it is claimed that the probability knowledge that teacher candidates receive in their undergraduate years is not sufficient; they cannot learn probability with different approaches, and therefore do not have the necessary competence to teach probability. In this case, it is necessary to examine the probability knowledge in terms of common content knowledge (CCK), advanced content knowledge (ACK), and specialized content knowledge (SCK) required to teach the probability of mathematics teacher candidates. In this study, probability content knowledge (CCK, ACK, and SCK) of mathematics teacher candidates was examined in the context of different meanings of probability (classical, frequentist, and subjective). According to the general results obtained by applying the probability content knowledge test, which was adapted to Turkish to 98 teacher candidates, it was found that the content knowledge in which participants were most successful was CCK and had a sufficient level of understanding for the classical meaning of probability. However, it was found that there are deficiencies in teacher candidates for ACK and SCK, and their understanding of the frequentist and subjective approach of probability is insufficient. It was recommended to improve and expand the scope of statistics and probability courses given during university education. In parallel, restructuring middle school mathematics programs could be applied to emphasize classical and other meanings of probability.

Keywords: Probability content knowledge, preservice elementary mathematics teachers, meanings of probability

DOI: $10.16949 /$ turkbilmat.728122
\end{abstract}

Öz: Olasılık öğretiminin uluslararası alanda gördüğü ilgi, Türkiye'de olasılığın ayrı bir öğrenme alanı olarak ele alınmasını sağlamış olsa da ortaokul matematik programında yoğunluğu azaltılmış ve hafifletilmiștir. Buna rağmen, ilköğretim matematik öğretmen adaylarının lisans öğrenimleri boyunca istatistik ve olasılık derslerine ayrıca yer verilmesi onların bu konuların öğretiminde yetiștirilmesi gerekliliğini göstermektedir. Fakat öğretmen adaylarının öğrenimleri boyunca aldıkları

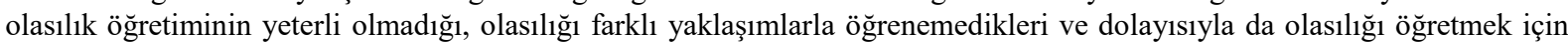
gerekli yeterliğe sahip olmadıkları iddia edilmektedir. Bu durum, matematik öğretmeni adaylarının olasılığı öğretebilmek için gereken temel alan bilgisi, ileri düzeyde alan bilgisi ve uzman düzey alan bilgisi bakımından olasıllk bilgilerinin incelenmesi gerekliliğini ortaya koymuştur. Bu çalışmada, matematik öğretmeni adaylarının olasılık alan bilgileri (temel, ileri ve özel) olasılığın farklı anlamları (klasik, sıklıkçı ve öznel) bağlamında incelenmiștir. Türkçe'ye çevrilerek uyarlanan olasılık alan bilgisi testinin 98 öğretmen adayına uygulanması ile elde edilen genel bulgulara göre, katılımcıların en başarılı oldukları alan bilgisinin temel düzeyde alan bilgisi olduğu ve olasılığın klasik anlamı için yeterli düzeyde bir anlayışa sahip oldukları görülmüştür. Fakat ileri düzeyde ve uzman düzey alan bilgisi için öğretmen adaylarının eksiklerinin bulunduğu, olasılığın sıklıkçı ve öznel yaklaşımına dair anlayışlarının yetersiz olduğu tespit edilmiştir. Çalışmada elde edilen sonuçlara göre, üniversite eğitimleri sırasında verilen istatistik ve olasılık derslerinin kapsamının iyileştirilmesi ve genişletilmesi ve paralel bir şekilde ortaokul matematik programlarının da olasılığın yalnızca klasik değil diğer anlamlarını da ön plana çıkarır şekilde yeniden yapılandırılması önerilmektedir.

Anahtar Kelimeler: Olasılık alan bilgisi, ortaokul matematik öğretmen adayları, olasılığın farklı anlamları

Türkçe sürüm için tıklayınız.

\section{Introduction}

In recent years, probability has been of considerable interest in mathematics education, and probability education and teaching studies have increased. This international interest in probability is reflected in mathematics education programs and teacher training programs in Turkey. The middle school mathematics curriculum, which began to be implemented in September 2013, was the first program in which the subject of probability was considered as a separate learning area (Ministry of National Education [MoNE], 2013). However, in the new curriculum published with the last update, the time allocated to probability is reduced, only the classical meaning of probability is emphasized, and many learning objectives previously included in the program (for example, the probability of dependent events) are also transferred to the high school level. The 
probability learning area is at the 8th-grade level with only five objectives, accounting for 7 percent of the current middle school mathematics program (MoNE, 2018). It can clearly be said that the relevant regulation is similar to the changes that the USA made in 1989, 2000, and 2006 in the framework of teaching probability (Langrall, 2018). When Langrall (2018) examines the programs of the countries covered by TIMMS 2015, he explains that this is true in many countries (teaching probability to students under 11). From this point of view, teacher candidates can receive support from technology (such as simulations). It can be said that more focus should be on key concepts in probability, and the idea of releasing deeper conceptual knowledge of probability to the high school level (Moore, 1997) is reflected in the content of the currently implemented middle school curriculum. When probability teaching is examined worldwide, although simple probabilistic thinking skills are given from pre-school level, it cannot be said that preservice mathematics teachers and even preservice primary teachers have received sufficient training in statistics and probability teaching during their university education (Batanero, Godino, \& Rao, 2004).

Considering today's emerging technologies and 21st century needs, it seems that the perspective on teaching probability needs to be updated. Besides, teaching probability "should take into account the characteristics of probability, its multifaceted views (classical, frequentist, subjective or axiomatic probability), common misconceptions, and wrong intuitions" (Estrada, Batanero, \& Díaz, 2018, p. 316). Different approaches to probability are related to the concept of uncertainty in probability and can be evaluated from three fundamentally different perspectives compared to other approaches (Batanero, Chernoff, Engel, Lee, \& Sánchez, 2016): subjective, classical, and frequentist approach (Hourigan \& Leavy, 2019). The classical approach to probability is an approach that until the 1980s was at the forefront of teaching, focusing on the ratio structure of probability and theoretical probability was at the forefront. This approach is the only approach that stands out when considering primary and middle school mathematics curriculum in our country, and it also ignores sample experiments that can be given by associating them with the context. According to the frequentist approach, the probability is defined as the limit of the relative frequency of the event when an experiment is repeated too many numbers, and it is also the most effective approach in today's universal teaching of probability. In our previous curriculum, the experimental probability was considered at the middle school level and associated with theoretical probability. This relationship was sent to the 11th grade in the secondary education mathematics curriculum published and implemented by the Ministry of National Education in 2018 (MoNE, 2018). According to the subjective approach, the probability is the personal rating of a belief, it can be updated with Bayes theorem when new information is obtained, and it has been suggested that this approach may also be involved in the teaching of probability in primary education (Gómez-Torres, Batanero, Díaz, \& Contreras, 2016). Although it is known that these three most basic different approaches of probability have various advantages or disadvantages on learning and teaching probability (Batanero, Henry, \& Parzysz, 2005), these they should be included in probability teaching, and the relationships between these approaches should be mentioned to students (Koparan, 2019). The inadequacy of the middle school mathematics teaching program in terms of probability is due to teaching delivery, highlighting only the classical meaning. From this perspective, the development of probability knowledge of middle school mathematics teachers during their university education is necessary to contribute to teaching probability. The teaching of probability and statistics and teaching mathematics must be different due to the nature of them (Batanero \& Díaz, 2012), and it is important to reflect this difference in the training of teacher candidates for teaching probability and statistics and to develop their understanding of probability and statistics (Jones \& Thornton, 2005; Stohl, 2005).

As in other learning areas, the most fundamental knowledge base for teaching probability is the teacher or preservice teacher's subject matter knowledge. In turn, this importance means having a good understanding of probability, common content knowledge (CCK), advanced content knowledge (ACK), and specialized content knowledge (SCK) (Ball, Thames, \& Phelps, 2008). CCK is a basic knowledge of mathematics that is not sufficient to teach mathematics but is necessary for any context. Knowledge of various mathematical symbols and representations, proper use, and knowledge of mathematical terminology can be given as examples for this type of content knowledge. ACK, Ball et al. (2008) brought it to the literature with the name of horizon knowledge, and it will be referred to as ACK here as in the studies of Gómez-Torres et al. (2016). It means that the teacher who deals with a curriculum to teach knows which concepts a concept can be associated with before (and after) its teaching at one level, at the previous (and after) levels. When we approach it in terms of the knowledge needed to teach probability, this knowledge means that teachers know the different meanings of probability and their relationships (Batanero, Godino, \& Roa, 2004). Gómez-Torres et al. (2016) have also addressed ACK to include knowledge that needs to be known about students and the content. The third knowledge type that can be considered within the framework of probability content knowledge required to teach probability is SCK (Hill, Ball, \& Schilling, 2008). SCK is the knowledge that teachers can explain a particular mathematical concept in-depth, give it with certain teaching methods, know and explain the forms of representation of relevant mathematical ideas (Hill, Ball, \& Schilling, 2008).

Studies examining teachers' probability content knowledge or their understanding of probability are limited (Gómez-Torres et al., 2016). One of the biggest reasons for this limitation may be that probability is relatively 
less involved in other subjects in the mathematics curriculum. According to Hourigan and Leavy (2019), the studies conducted are mostly studies that examine common misconceptions, errors, heuristic misconceptions (bias), or learning difficulties of teachers or prospective teachers regarding probability concepts. Batanero, Godino and Cañizares (2005) found that the three most basic probability misconceptions that prospective middle school mathematics teachers have are: representativeness bias, equiprobability bias, and outcome approach.

According to studies that examined the probability content knowledge of teachers and prospective teachers, participants were found to be weaker in the probability and statistics than in other learning areas, their understanding of probability was little, and they found it more difficult to teach the one than others (Shaughnessy, 1977; Stohl, 2005; Quinn, 1997). Thus, statistics and probability are considered difficult topics to learn or understand (Olpak, Baltaci, \& Arican, 2018; Stohl, 2005). There are studies which examine not only the knowledge needed to teach, but also the attitudes of teachers and prospective teachers to statistics and probability (for example, Estrada, Batanero, \& Díaz, 2018), which examine pedagogical content knowledge of probability (ex. Danişman \& Tanışl1, 2017), in concepts of probability (ex. dependent probability, chance, sample space), which examine misconceptions and beliefs about probability (for example, Bursal1, \& Gökkurt-Özdemir, 2019; Stohl, 2005), and which examines conceptual and procedural levels of knowledge about probability (e.g., Ata, 2014; Karaaslan \& Ay, 2017; Kurt-Birel, 2017). A study to develop a test to measure teacher candidates' understanding of statistics and probability at a cognitive level is also a study that measures teacher candidates' statistical reasoning skills (Arican \& Kuzu, 2020). As Arican and Kuzu (2020) concluded, it was found that teacher candidates had difficulty making statistical inferences and had difficulty understanding and applying basic concepts of probability. In general, studies examining the probability content knowledge of teachers and prospective teachers are similarly small due to the volume of probability in the middle school mathematics program is less than others, and the intensity is eased over time. It shows that the importance given to probability is also gradually decreasing. The study outlined here is important in studying prospective mathematics teachers according to different probability content knowledge types for different meanings of probability.

Various measurement tools are needed to evaluate teacher candidates' probability content knowledge and prepare the probability courses they can attend. This study includes the adaptation of the test developed by Gómez-Torres et al. (2016) to assess the probability content knowledge of middle school mathematics teacher candidates to Turkish and the application of the adapted test.

Therefore, this study aims to examine the probability content knowledge of middle school mathematics prospective mathematics teachers on the different meanings of probability within the framework of the knowledge needed to teach mathematics. To this end, the research question is as follows: "What is the level of probability content knowledge of preservice middle school mathematics teachers according to the different meanings of probability and the knowledge needed to teach mathematics?"

\section{Method}

This study is a survey study as it involves adapting and applying a test to examine the level of probability content knowledge of mathematics teacher candidates. Survey research involves examining a phenomenon according to various variables or factors and analyzing the findings according to these variables (Fraenkel \& Wallen, 2006; Karasar, 2005).

\subsection{Participants}

Ninety-eight middle school mathematics teacher candidates at the 3rd and 4th-year, 42 of whom were studying at the faculty of education of Mersin University, participated in the study. Participants were selected from students who took the statistics and probability courses in the fall and spring semesters of the elementary mathematics teaching program, which were given 2 hours of theoretical and 2 hours of practical. In the education faculty programs organized by the Higher Education Council (HEC) in the 2018-2019 academic year, there are two-hour probability course in the fall semester and two-hour statistics course in the spring semester, and the number of hours has been reduced by half compared to the previous undergraduate program. The course content has not been changed and generally includes counting (rules, permutation, combination), introduction to probability, random variables and distributions, discrete and continuous probability distributions, data analysis, confidence intervals, and hypothesis testing correlation, regression.

\subsection{Data Collection Tool}

This study included adapting the test prepared by Gómez-Torres et al. (2016) to Turkish, and the adapted version was applied to middle school mathematics teacher candidates to assess their probability content knowledge. The test, which was translated into Turkish, consists of open-ended questions. In preparing the test, three different meanings of the probability that the items bring to the fore were also considered (Batanero, Henry, \& Parzysz, 2005). As a result of their work, the research team developed a 12-item test. They explained that the test measured probability content knowledge validly and reliably (Cronbach alpha $=0,768$ ), along with 
different content knowledge components and different meanings of probability, and they also studied their probability content knowledge by applying it to the teacher candidates (Gómez-Torres et al., 2016). For the Turkish version of the test, the Cronbach alpha value was obtained as 0.82 .

The 12 items selected for this test were from the studies of Azcárate (1995), Batanero, Garfield, and Serrano (1996), Chernoff (2011), Díaz and Batanero (2009), Falk and Wilkening (1998), Fischbein and Gazit (1984), Green (1982, 1983) and Shaugnessy and Ciancetta (2002), including basic probability concepts, dependentindependent events, probability estimation, conditional probability, sampling, equipotential events, the binomial distribution. The type of content knowledge the test questions evaluate and which approach of probability bring to the fore are shown in Table 1 below. The entire test is included in Appendix 1 at the end of the study.

Table 1. The type of content knowledge and the meaning of probability of test items

\begin{tabular}{|c|c|c|}
\hline Common Content Knowledge (CCK) & Meaning of Probability & Item \# \\
\hline Listing possible outcomes & Classical & 1 \\
\hline Comparing probabilities & Classical & 2 \\
\hline $\begin{array}{l}\text { Joint probability (product rule): Independent } \\
\text { experiments }\end{array}$ & Classical & 3 \\
\hline $\begin{array}{l}\text { Joint probability (product rule): Dependent } \\
\text { experiments }\end{array}$ & Subjective & 4 \\
\hline Estimating probability & Frequentist & 5 \\
\hline Fair game & Classical & $6 \mathrm{a}$ \\
\hline \multicolumn{3}{|l|}{ Advanced Content Knowledge (ACK) } \\
\hline Expectation & Classical & $6 \mathrm{~b}$ \\
\hline Conditional probability & Subjective & 7 \\
\hline Equiprobability bias & Classical & 8 \\
\hline Sampling & Frequentist & 9 \\
\hline Perception of randomness & Frequentist / Subjective & 10 \\
\hline Representativeness heuristic & Frequentist / Subjective & $11 \mathrm{a}$ \\
\hline Binomial distribution & Frequentist / Subjective & $11 b$ \\
\hline Outcome approach: Prediction & Frequentist & $12 \mathrm{a}$ \\
\hline Outcome approach: Validity of prediction & Frequentist / Subjective & $12 b, 12 c$ \\
\hline Specialized Content Knowledge (SCK) & & $\begin{array}{c}\text { Arguments in the items } \\
2,3,4,6 a, 10,11 \mathrm{a}, \\
11 \mathrm{~b}, 12 \mathrm{~b}\end{array}$ \\
\hline
\end{tabular}

The data from the test applied to the participants was collected in two sessions; the first session was conducted with a group of 63 3rd and 4th-year students who were preservice middle school mathematics teachers studying in the 2017-2018 academic year. Later, it was decided to expand the sample, and therefore, the second session was also applied to the 4th year students studying in the 2019-2020 academic year.

\subsection{Data Analysis}

The data obtained by applying the test was scored in the format applied by Gómez-Torres et al. (2016), who developed the test, and the maximum score that can be obtained from the test is 34 if all questions and their justifications are answered correctly. For example, as shown in Table 2, the maximum score obtained from the first question is 3: the value of sub-questions in the form of listing the sample space with 3 and 4 elements, and developing a strategy for it is one point. Some of the test questions, such as question 11, measure the meaning of the probability that prospective teachers use. Accordingly, attention has also been paid to the scoring for these questions. For example, students can justify the answers they give using the representativeness and binomial distribution for the 11th question in the frequency or subjective sense of probability. Using the representativeness and the binomial distribution for question 11, for instance, students can justify their answers in the frequentist or subjective approach. Again, in the scoring for this question, it was scored with a total of 4 points, giving 1 point if the items $11 \mathrm{a}$ and $11 \mathrm{~b}$ were answered correctly, and 1 point for each correct reasonings of these answers. Test items that examine SCK are measured by scoring the participants' reasonings when answering previous related test items. For example, the student who answers correctly to item 6a states that the game is unfair (CCK) and justifies this (SCK).

In summarizing the results, two characteristics of the test were discussed: the type of probability content knowledge (CCK, ACK, and SCK) and the different meanings of probability (classical, frequentist, and subjective meaning). Therefore, the findings were first examined in detail under these headings and then explained in general. The item difficulty and item discrimination indices of the test questions were calculated using TAP (Test Analysis Program), which is a program available free of charge. According to the results obtained, it can be said that the difficulty levels of the test items fluctuate between $3 \%$ and $95 \%$, and there are 
many items at different difficulty levels, and the number of correct answers decreases in the items where the justification for the answer is desired. Table 2 below shows each question, the explanation of the question, what type of content knowledge it measures, and what meaning of probability it highlights, item difficulty, and item discrimination index scores.

Table.2. Item difficulty and item discrimination scores of test items

\begin{tabular}{|c|c|c|c|c|c|}
\hline & $\begin{array}{l}\text { Meaning of } \\
\text { probability }\end{array}$ & Item & Item explanation & $\begin{array}{c}\text { Item } \\
\text { difficulty }\end{array}$ & $\begin{array}{c}\text { Item } \\
\text { discrimination }\end{array}$ \\
\hline \multirow{11}{*}{ 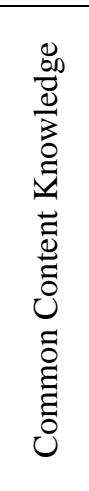 } & \multirow{5}{*}{ Classical } & 1a & Listing sample space (3 elements) & 0,95 & 0,13 \\
\hline & & $1 b$ & Listing sample space ( 4 elements) & 0,92 & 0,21 \\
\hline & & $1 b$ & Strategy & 0,82 & 0,23 \\
\hline & & 2 & Comparing probabilities & 0,82 & 0,26 \\
\hline & & 3 & Joint probability. Independent experiments. & 0,86 & 0,23 \\
\hline & \multirow{3}{*}{ Subjective } & $4 \mathrm{a}$ & Dependent compound experiment: Most likely result & 0,79 & 0,51 \\
\hline & & $4 \mathrm{~b}$ & Dependent compound experiment: Least likely result & 0,72 & 0,64 \\
\hline & & $4 \mathrm{c}$ & Consistency between response to $4 \mathrm{a}$ and $4 \mathrm{~b}$ & 0,43 & 0,7 \\
\hline & \multirow{2}{*}{ Frequentist } & $5 \mathrm{a}$ & Estimating probability & 0,26 & 0,32 \\
\hline & & $5 \mathrm{~b}$ & Sampling variability & 0,31 & 0,22 \\
\hline & Classical & $6 a$ & Fair game & 0,93 & 0,08 \\
\hline \multirow{15}{*}{ 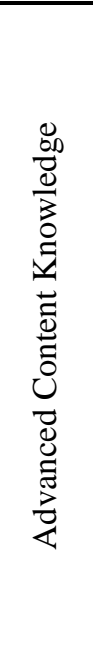 } & \multirow{2}{*}{ Classical } & $6 \mathrm{~b}$ & Expectation & 0,30 & 0,40 \\
\hline & & $6 \mathrm{~b}$ & Strategy & 0,29 & 0,4 \\
\hline & \multirow{2}{*}{ Subjective } & 7 & Conditional probability & 0,57 & 0,51 \\
\hline & & 7 & Strategy & 0,50 & 0,57 \\
\hline & Classical & 8 & Independent compound experiment: Equiprobability & 0,01 & $-0,03$ \\
\hline & \multirow{4}{*}{ Frequentist } & $9 \mathrm{a}$ & Sampling: Total estimation & 0,40 & 0,8 \\
\hline & & $9 \mathrm{a}$ & Strategy & 0,38 & 0,77 \\
\hline & & $9 b$ & Re-sampling: Predicting a second sample & 0,34 & 0,67 \\
\hline & & $9 \mathrm{~b}$ & Strategy & 0,12 & 0,27 \\
\hline & \multirow{3}{*}{$\begin{array}{l}\text { Frequentist } \\
\text { /Subjective }\end{array}$} & 10 & Perception of randomness & 0,53 & 0,45 \\
\hline & & $11 \mathrm{a}$ & Representativeness heuristics: Insensibility to & 0,11 & 0,23 \\
\hline & & $11 b$ & Binomial distribution & 0,20 & 0,34 \\
\hline & Frequentist & $12 \mathrm{a}$ & Outcome approach: Predicting an average & 0,57 & 0,41 \\
\hline & Frequentist & $12 b$ & The validity of forecast with one contradictory & 0,45 & 0,6 \\
\hline & /Subjective & $12 \mathrm{c}$ & The validity of forecast with two contradictory & 0,28 & 0,47 \\
\hline \multirow{8}{*}{ 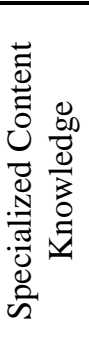 } & \multirow{2}{*}{ Classical } & 2 & Comparison of probabilities (Justification) & 0,61 & 0,41 \\
\hline & & 3 & Joint probability: Independent experiments & 0,65 & 0,65 \\
\hline & \multirow{2}{*}{ Subjective } & 4 & Joint probability: Dependent experiments & 0,41 & 0,6 \\
\hline & & $6 a$ & Fair game (Justification) & 0,85 & 0,4 \\
\hline & \multirow{4}{*}{$\begin{array}{l} \\
\text { Frequentist } \\
\text { /Subjective }\end{array}$} & 10 & Perception of randomness (Justification) & 0,40 & 0,42 \\
\hline & & $11 \mathrm{a}$ & Representativeness heuristic (Justification) & 0,03 & 0,08 \\
\hline & & $11 \mathrm{~b}$ & Representativeness heuristic: Bin. distr. & 0,07 & 0,11 \\
\hline & & $12 b$ & Outcome approach: Validity of forecast & 0,18 & 0,19 \\
\hline
\end{tabular}

\section{Findings}

The results are summarized below according to the types of probability content knowledge of middle school mathematics teacher candidates: CCK, ACK, and SCK. Each subheading contains an assessment of questions that question the classical, frequentist, and subjective meanings of content knowledge type of probability.

\subsection{Assessment of Common Content Knowledge (CCK)}

There are 11 question items in this area, and the lowest and highest results are 0 and 11 points. In this part, one student received 2 points, which is the lowest score, and five students managed to get 11 points, which is the highest score. The average score was 7.79. The results obtained for this section are given below with the chart and frequency table in Figure 1. 


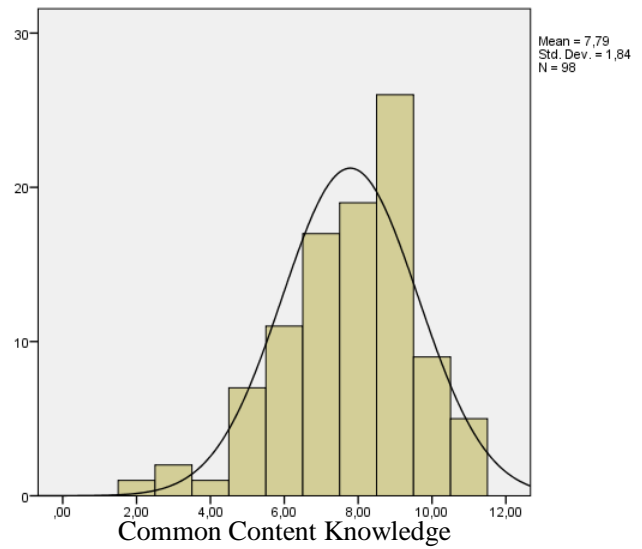

\begin{tabular}{|c|c|c|}
\hline Score & Frequency & Percentage \\
\hline 2,00 & 1 & 1,0 \\
\hline 3,00 & 2 & 2,0 \\
\hline 4,00 & 1 & 1,0 \\
\hline 5,00 & 7 & 7,1 \\
\hline 6,00 & 11 & 11,2 \\
\hline 7,00 & 17 & 17,3 \\
\hline 8,00 & 19 & 19,4 \\
\hline 9,00 & 26 & 26,5 \\
\hline 10,00 & 9 & 9,2 \\
\hline 11,00 & 5 & 5,1 \\
\hline Total & 98 & 100,0 \\
\hline \multicolumn{3}{|c|}{} \\
\hline
\end{tabular}

Figure.1. Frequency distribution displays of the participants' CCK

In general, CCK of the classical meaning of probability is acceptable, as in Torres (2016), with an average of 7.79. The vast majority of students correctly answered questions about sample space sequencing, probabilities, independent events, and fair play with a small number of elements. The most commonly used method for listing the sample space is the factorial operation and the box method (the first box is for the first draw, the second box is for the second draw). Only a small number of students did not use a systematic approach to sorting the outputs of sample spaces with 3 and 4 elements ( 7 and 10 students, respectively). To achieve a solution to the second question, students answered largely correctly (82\%), going down the path of explaining the situation using visuals, but even though there were two different correct answers, no one mentioned either of them. Some participants tried to solve this question by creating equations and using two different unknowns as $\mathrm{x}$ and $\mathrm{y}$. However, it can be said that they also had difficulty interpreting the result they found afterward. In question 6 (6a), students answered correctly, stating that $93 \%$ of the game was unfair. In short, it can be said that students are good enough to understand and apply the classical meaning of probability in terms of CCK.

CCK about the frequentist meaning of probability was examined with the thumbtack question. In this item, only a quarter of the students made a probability estimate from the experiment on the pins' posture direction. The correct response rate remained at $31 \%$ when it came to writing possible results that would occur by repeating the experiment. In addition to the students (26\%) who gave very inconsistent results with each other (question $5 b$ ), there are students who wrote a possible result (question 5a) considering that the positions of the pushpins pointing up and down as equally likely without considering the probabilities in the first experiment (question 5a). Answers such as 50-50, 1-99, 90-10 were also found among the possible estimates requested among the incorrect answers. In summary, it seems that the CCK about the frequency of probability is not sufficient.

CCK of the subjective meaning of probability was studied with the trap maze question ( $4 \mathrm{a}$, $4 \mathrm{~b}$, and $4 \mathrm{c})$. More than half of the students gave the correct answer (79\% and $72 \%$, respectively) to $4 \mathrm{a}$ and $4 \mathrm{~b}$ items related to dependent events. When the correct answers were examined, it was observed that they calculated the probability for each path to the traps and multiplied these probabilities for each path separation. However, consistency was observed to be low (43\%). Some students gave the correct answer without calculating any probability, citing the differences in the way that some of them encountered until they reached the traps. For example, they said they are less likely to be caught in traps because there are few options (road separation). Similarly, participants claimed that the paths to traps $5,6,7$, and 8 were more likely to go because the path separations seem linear. Therefore, it can be said that prospective teachers lack the subjective meaning of probability within the scope of the CCK.

\subsection{Assessment of Advanced Content Knowledge (ACK)}

There are 15 question items in this area, and between 0 and 15 points are scored, and three students have never been able to answer correctly. There are no students who manage to get 15 full points. Figure 2 below clearly shows the scores and frequencies that students receive. The average score was 5.04. 


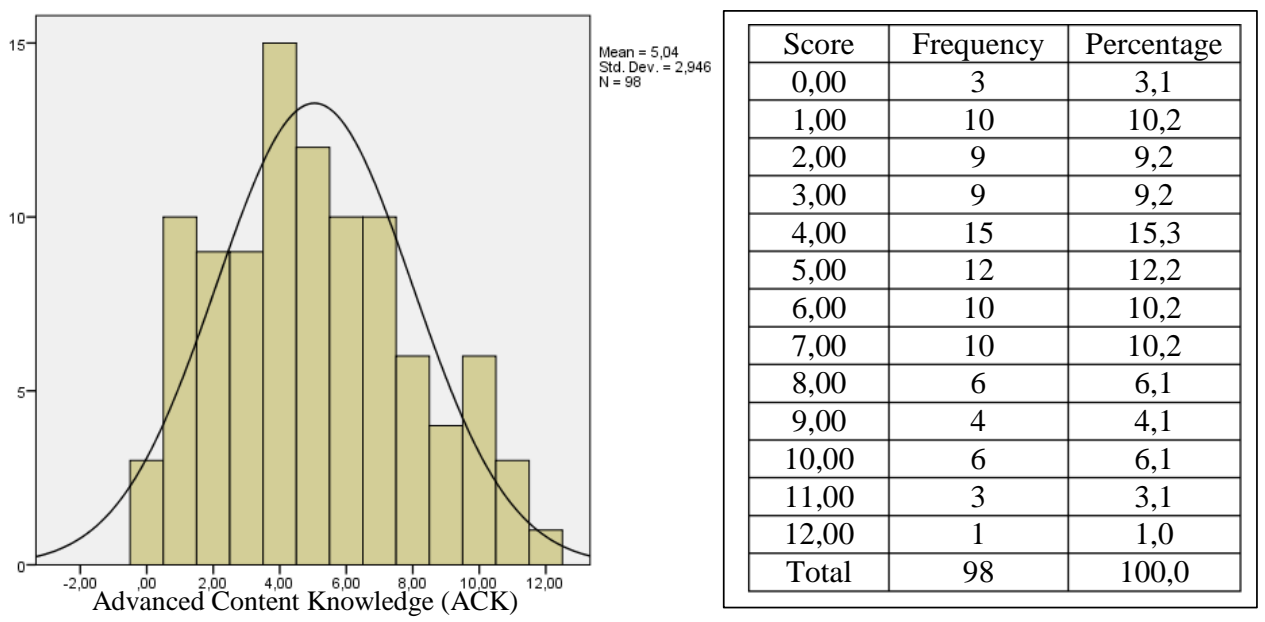

Figure.2. Frequency distribution displays of the participants' ACK

ACK of the classical meaning of probability was examined with questions 6 and 8. In question 6, which asks whether a game played with two dice is fair, there are few students $(29 \%)$ who can explain why the game is not fair, and only $30 \%$ of students were able to determine how much players should take for the game to turn into a fair game. In the 8th question, which was about rolling three dice, about half of the students left the question blank, and almost all of the others answered incorrectly. In the experiment, where they were asked to find the triple with the highest probability, students perceived these outputs as sequential triples and therefore ranked the dice may explain the reason for the incorrect answers given. As a result, prospective teachers' ACK of the classical meaning of probability is very low and needs improvement.

ACK of the frequency meaning of probability was examined with questions 9-12. In the question (9a) related to fish number estimation, students answered $40 \%$ correctly in the sample size estimation. As for making a second guess (9b), the ability to answer correctly is $34 \%$. However, especially making a second guess, it has been observed that students make predictions at random or incorrect rates, where they do not use correct reasoning. Accordingly, it can be said that students are not sufficient to estimate the size of the universe based on sample information. In other questions, the correct answer rate appears to be at or below moderate levels. For example, in the 10th question, it is observed that the correct answer rate of which of the two people obtained random results was approximately moderate, with 53\%. When prospective teachers examined the wrong answers to this question, it was observed that Barıș made up the series because he wrote too many 1 or 0 sides to side, or that Deniz's series was more realistic when shots were examined in consecutive duos. Similarly, in the 12th question about weather forecasting, students correctly predict how many days of the year there will be precipitation by $57 \%$, but in contradictory cases 1 and 2, this figure is only below average with $45 \%$ and $28 \%$. When the wrong answers were examined, it was observed that beyond interpreting the forecast to be good or bad, they made predictions about how many days could be rainy.

ACK of the subjective meaning of probability can be said to be generally moderate. In question 7a, which is related to the experiment in which two different colored dice were thrown, the answers to conditional probability were $57 \%$ correct, but the vast majority $(50 \%)$ of them were given by adhering to the definition of conditional probability. Although they can sort all possible outcomes desired due to the experiment, some students miscalculate the probability. In contrast, in the 11th question, in which the probability of male babies born in the hospital was calculated, it was observed that students were insufficient (20\%) to reach a solution regardless of the sample size (11a) and with the help of binomial distribution (11b). Considering the sample size, students who claim that within 10 or 100 births, the probability of having a baby boy will not be equal is $11 \%$.

\subsection{Assessment of Specialized Content Knowledge (SCK)}

Eight items focus on all the meanings of probability within the scope of SCK, and scores can be obtained between 0 and 8 points. All these items are questions related to the justification of the answers given to the relevant questions. The ability to justify and explain their response indicates whether students are sufficient in the SCK needed to teach probability. While two students receive no points at all, there are no students with full scores. Figure 3 shows the frequencies of the scores obtained by students from the type of SCK. The average score was 3.20. 


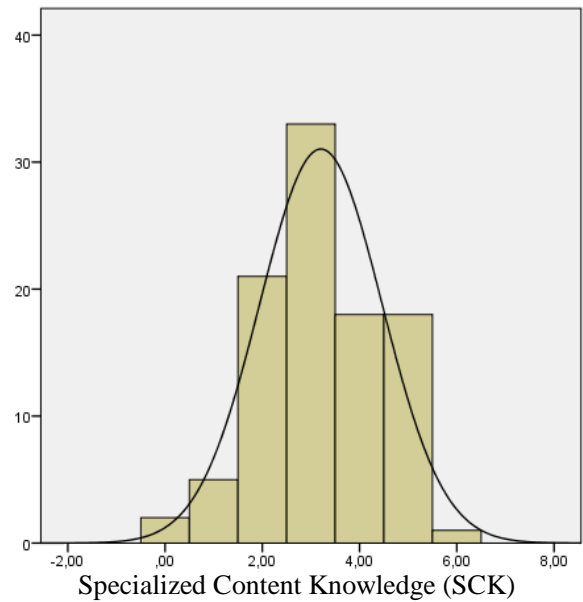

Mean $=3,20$
Stald Dev.
$\mathrm{N}=98$
\begin{tabular}{|c|c|c|}
\hline Score & Frequency & Percentage \\
\hline 0,00 & 2 & 2,0 \\
\hline 1,00 & 5 & 5,1 \\
\hline 2,00 & 21 & 21,4 \\
\hline 3,00 & 33 & 33,7 \\
\hline 4,00 & 18 & 18,4 \\
\hline 5,00 & 18 & 18,4 \\
\hline 6,00 & 1 & 1,0 \\
\hline Total & 98 & 100,0 \\
\hline
\end{tabular}

Figure 3. Frequency distribution displays of the participants' SCK

SCK of the classical meaning of probability was assessed by their justifications of the answers of questions 2 and 3. These problems have a high correct response rate with $61 \%$ and $65 \%$ with a comprehensible solution. Therefore, it can be said that the reasons that students make about comparing probabilities and independent experiments in common events are sufficient and that their understanding of the subject is good.

Participants' SCK on the frequency meaning of probability was examined with items 10, 11a, 11b, and 12b, and students were found to be at a very poor level $(40 \%, 3 \%, 7 \%$, and $18 \%$, respectively). In summary, even if the students answered the questions correctly, they failed to show rational and consistent reasons. For example, since the 80-90 range was wider than the 8-9 range, it was observed that students felt the correct answer intuitively when it came to calculating the probability of the number of male babies born in the hospital. However, this answer was not considered correct, as it was not associated with the subject of sample size. Similarly, for item $11 \mathrm{~b}$, it can be said that students intuitively give more consistent answers than 11a, but this question is also not considered correct, as justifications that are mostly independent of the binomial distribution are presented.

Questions in which subjective probability is examined in SCK are items of 4 and 6a. Especially in item 6a, which examines the fair game, students' rates showing rational and correct reasons are good at $85 \%$. However, this high level was not reached in question $4(41 \%)$. Although the prospective teachers' answers about the likelihood of being caught in traps were highly accurate, the reasons they presented were not sufficiently consistent or rational. The discrepancy mentioned here is that they did not offer similar justifications when explaining how the probability of being caught in a trap is minimal or high.

\subsection{General Findings}

Scores range from 0 to 34 . In order to get 34 points, all the answers and reasonings must be correct. In Figure 4 below, as seen in the frequency and percentage table and distribution of the participants' scores for the total scores, no students received full points. The lowest score is 5 , and the highest score is 26 .

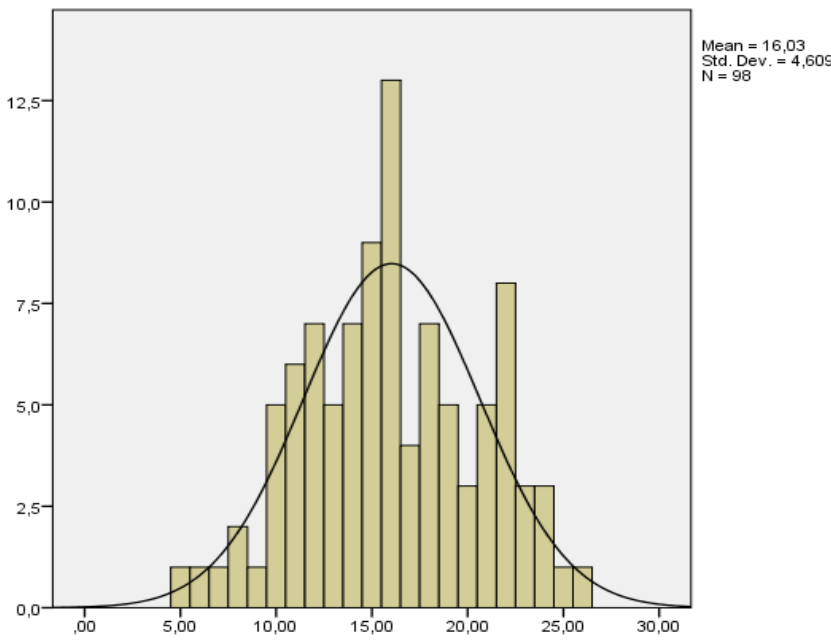

\begin{tabular}{|c|c|c|}
\hline Score & Frequency & Percentage \\
\hline 5,00 & 1 & 1,0 \\
\hline 6,00 & 1 & 1,0 \\
\hline 7,00 & 1 & 1,0 \\
\hline 8,00 & 2 & 2,0 \\
\hline 9,00 & 1 & 1,0 \\
\hline 10,00 & 5 & 5,1 \\
\hline 11,00 & 6 & 6,1 \\
\hline 12,00 & 7 & 7,1 \\
\hline 13,00 & 5 & 5,1 \\
\hline 14,00 & 7 & 7,1 \\
\hline 15,00 & 9 & 9,2 \\
\hline 16,00 & 13 & 13,3 \\
\hline 17,00 & 4 & 4,1 \\
\hline 18,00 & 7 & 7,1 \\
\hline 19,00 & 5 & 5,1 \\
\hline 20,00 & 3 & 3,1 \\
\hline 21,00 & 5 & 5,1 \\
\hline 22,00 & 8 & 8,2 \\
\hline 23,00 & 3 & 3,1 \\
\hline 24,00 & 3 & 3,1 \\
\hline 25,00 & 1 & 1,0 \\
\hline 26,00 & 1 & 1,0 \\
\hline Total & 98 & 100,0 \\
\hline
\end{tabular}

Figure 4. Frequency distribution displays of the participants' overall test results 
The box plot for content knowledge is shown in Figure 5 below. It seems that the average score of CCK is better than others. Participants are generally acceptable in terms of CCK. Only three participants (those who scored 2 and 3) are separated from the others and are not at an acceptable level.

ACK scores range from 0 to 12 , but there are no participants with 15 full scores. Unfortunately, three students received zero points, while ten students received 1 point. The students' average score for ACK is 5 points, and the proportion of those who score above the average is $40 \%$. Remedial work should be done on learning areas at this level.

SCK with the lowest average score has an average score of 3, with about $38 \%$ of students scoring above average. Although scores range from 0-6, there is only one student who gets six points. There are two students with zero points and five students with one point. As can be seen from the item difficulty data at this level, the correct response rates are acceptable, except for three items. However, the correct response rate is dramatically low in $11 \mathrm{a}$ and $11 \mathrm{~b}$ because of not-taking into account sample size and binomial distribution. Similarly, a low correct response rate was observed in item $12 \mathrm{~b}$.

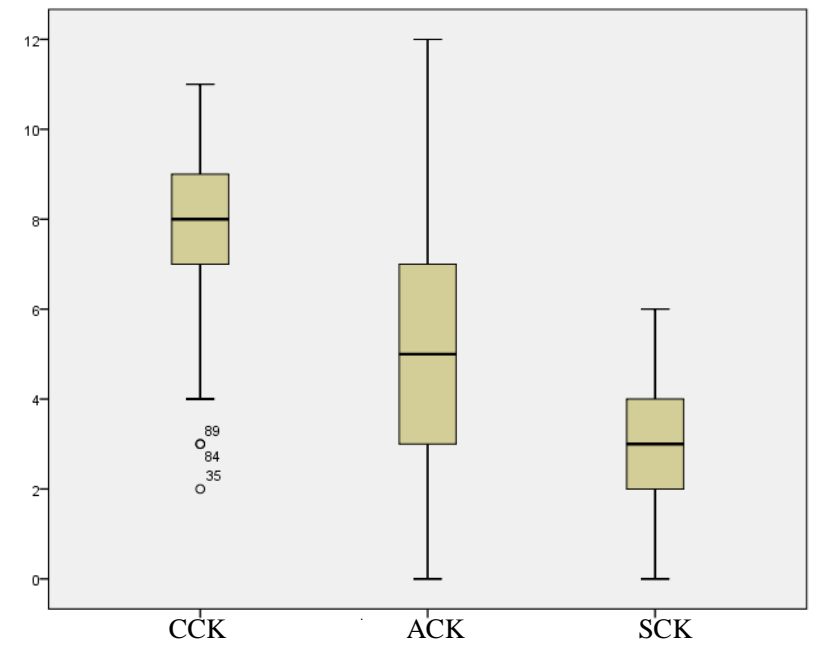

Figure 5. Box plot of the participants' knowledge level according to knowledge type

Below is a comparison of the participants' scores in terms of the meaning of probability in the chart given in Figure 6. When the graph is examined, it can be said that students have an acceptable average in terms of classical meaning. Only two students were able to score well below average. In contrast, frequentist and subjective understandings have a wider range of changes but are shown on average. In the frequentist approach to probability, four students produced higher scores than others.

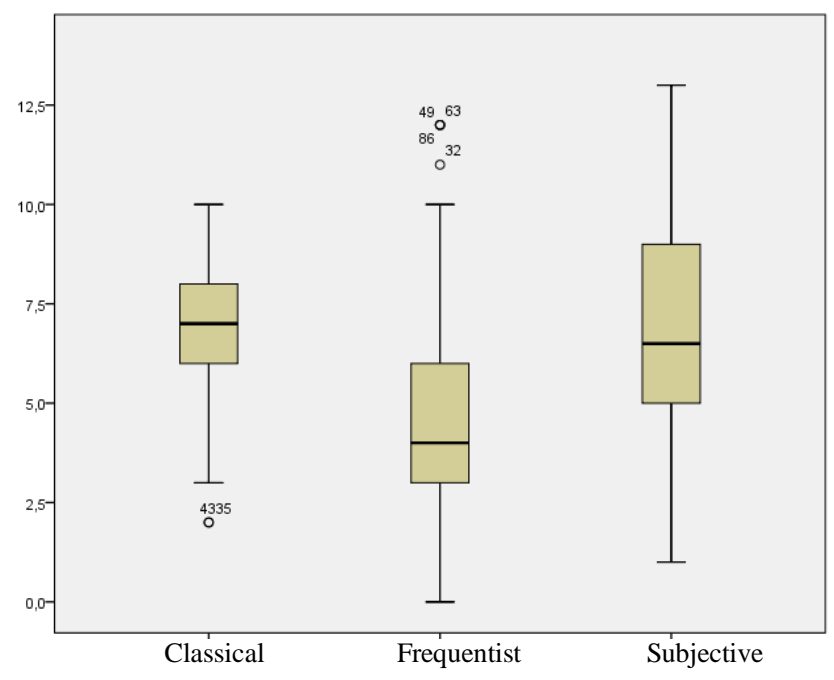

Figure 6. Box plot of the participants' scores according to the meaning of probability

\section{Discussion and Conclusion}

This test, adapted to Turkish, is intended to assess middle school mathematics teacher candidates' probability content knowledge in two dimensions (the meaning of probability and the type of content knowledge) mentioned above. This study provides a source of information that can be applied to the development and design of courses, 
such as teaching probability topics that can be proposed for teacher candidates and reviewing the content of statistics and probability courses.

The fact that the probability content knowledge of teacher candidates is at a low level at almost all kinds of content knowledge, the lack of sufficient attention to probability in the secondary school mathematics program, the relatively small percentage of probability learning space in the program compared to other learning areas, may cause the teacher candidates not to be interested or care about the teaching of probability. Besides, some studies claim that the beliefs of teacher candidates are also effective in knowledge of probability (Danişman, \& Tanışl1, 2017). It prevents prospective teachers from having a motivation to learn more deeply about the probability. On the other hand, applying probability only to solve the meaning of games of chance has caused mathematics teachers to perceive probability as a sub-branch of mathematics and reflect it in this way in their teaching. Despite all this, increasing interest in statistics has also allowed the concepts of probability to begin to be given experimentally (Batanero, Henry, \& Parzysz, 2005). Today's exam-oriented education system and students' constant exposure to multiple-choice questions cause this trend of probability not to be caught and may lead students and teachers to take probability seriously increasingly.

To establish a relationship between probability concepts and have an adequate level of understanding, we need the teaching of probability that includes different meanings of probability. Besides, this expected relationship between probability concepts can also be presented in different contexts than games of chance, making the probability meaningful not only for students but also for teachers (Koparan, 2019). Similarly, Koparan (2019) also revealed that there should be more room for simulation, games, activities, materials, and others in probability teaching. These results suggest that it is necessary to reevaluate teaching probability methods at both the middle/high school and undergraduate level.

Another result of this study is that the prospective teachers could not intuitively explain what they knew at an ACK or SCK. To be associated with this result, the probability content knowledge of preservice teachers shows similar results when examined in the context of procedural and conceptual knowledge (Ata, 2014; Kurt-Birel, 2017). The researcher revealed that the preservice teachers' both conceptual and procedural understanding of the different meanings of probability (theoretical, experimental, and subjective meanings) were insufficient, and even there was a positive relationship between these two (Ata, 2014).

The findings of our study also show that the preservice teachers could not generate strategies in solving the questions or that the strategies they presented did not differ. This result shows that the prospective teachers' probability content knowledge is not deep at advanced and specialized types, they cannot explain the results they found, and their understanding of the different meanings of probability is limited and at a narrow level.

When we examine the answers given by the participants to the questions examining the probability bias (11), equiprobability bias (8), and the outcome approach (12), which are the probability misconceptions that teachers or preservice teachers have the most problems with, we observe that the questions with the lowest points are the questions. We can claim that the results coincide with previous literature (Bursalı \& Gökkurt-Özdemir, 2019; Hourigan \& Leavy, 2019; Stohl, 2005). We can also conclude that the participants' ACK and SCK about these concepts are quite insufficient. The success rate below 0.05 in the question (8) about equiprobability bias may indicate that the participants may not understand this question due to translation. When we examine our participants' responses to the question items $(11 \mathrm{a}$ and $11 \mathrm{~b})$ related to the representation shortcut, it shows that they could not use the binomial distribution they were expected to use for the solution or did not develop any other strategy. Their knowledge of probability at both ACK and SCK was insufficient. Similarly, when examining the incorrect answers given to the weather-related question (12), we can argue that the participants were mistaken about the outcome approach. Participants tried to decide on the certainty of the event, rather than commenting on how good it was.

As a result, we can say that preservice teachers' probability domain knowledge is insufficient, both at common and advanced levels and that they have a limited understanding of the different meanings of probability. When the participants' responses are examined, we can argue that the findings also indicate the misconceptions previously determined in the literature. The findings obtained are that the concepts of probability and statistics are being taught without being adequately associated (Hourigan \& Leavy, 2019) and even being included as separate learning areas in the middle school mathematics curriculum, secondary school mathematics teachers and teacher candidates do not give enough importance to probability, students. Therefore, teacher candidates are also It may have been caused by the fact that he was too prone to memorize within the framework of the multiple-choice examination-based system.

\section{Recommendations}

According to the findings of the study, some suggestions can be made regarding the teaching of probability in terms of middle school mathematics teaching and teacher education: First of all, the probability learning area in the secondary school mathematics curriculum should be reconsidered in a way that includes different 
meanings of probability. This suggestion will also enable the teachers responsible for their teaching to learn more about these topics. Besides, probability teaching should occur more in the primary and secondary school mathematics curriculum, starting at earlier levels. As a second suggestion, the probability that prospective mathematics teachers took at university should be reviewed by correlating the content of statistics courses, probability and statistics concepts and highlighting the different meanings of probability. Increasing teachers' probability content knowledge at all three levels should be determined as one of these lessons' aims. In this sense, these courses should provide information about the misconceptions experienced in probability teaching and where they may arise.

Appendix 1. Probability Content Knowledge Test (Gómez-Torres et al. (2016)

Solve the following tasks, explaining your solution in writing when required to do so:

Item 1. Three boys take turns playing a video game. They have to line up in a row and wait for their turn. Suppose the boys are called Andres, Benito and Carlos (A, B, C, for short). We want to write down all of the possible orders in which they could play this game: for example, one possible order is BCA.

a. Write down all of the different orders. How many different ways are there altogether?

b. If four boys (A, B, C, D) want to play, how many different ways are there?

Item 2. Pablo puts 5 white balls and 7 black balls into an urn. Miguel puts 3 white balls and 5 black balls into another urn. How many black or white balls should be moved from one urn to another if we want both children to have the same chance of drawing a black ball? Why?

Item 3. These two fair spinners are part of a carnaval game. A player wins a prize only when both arrows land on black after each spinner has been spun once.

a. What is the probability of winning the game?

b. Why?

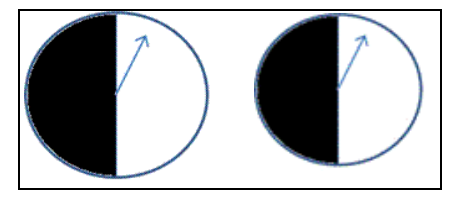

Item 4. A robot is put into a maze, which it begins to explore. At each junction, the robot is as likely to follow any one path as any other (however, it will not go back the way it came). There are eight traps at the of each of the eight paths (see the picture).

a. In which trap (or traps) is the robot most likely to finish up? Why?

b. In which traps or traps is the robot least likely to finish up? Why?

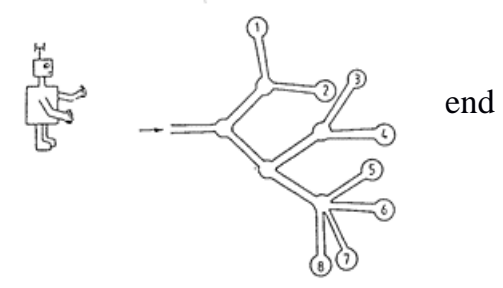

Item 5. A packet of 100 drawing pins is emptied out onto a table by a teacher. Some drawing pins landed "up" 5 and some landed "down" 2 . The results were as follows: 68 landed up and 32 landed down. The teacher then asked four students to repeat the experiment. Each student emptied a packet of 100 drawing pins and got some landing up and some landing down. In the following table, write possible results for each student:

\begin{tabular}{|l|l|l|l|}
\hline \multicolumn{1}{|c|}{ Daniel } & \multicolumn{1}{c|}{ Martin } & \multicolumn{1}{c|}{ Diana } & \multicolumn{1}{c|}{ Maria } \\
\hline up: & up: & up: & up: \\
\hline down: & down: & down: & down: \\
\hline
\end{tabular}

Item 6. Miguel and Luis play a game that involves rolling two fair dice (each numbered from 1 to 6). They roll both dice and multiply their numbers.

- Miguel receives 1 euro if the product is an even number

- Luis receives 1 euro if the product is an odd number

a. Is this game fair? Why?

b. If Miguel receives 1 euro every time the product of both dice is even, how many euros should Luis receive every time the product is odd if the game is to be fair?

Item 7. Two dice (one red and one blue die) are rolled, and the product of the two resulting numbers is 12 . What is the probability that one of the two numbers is a six? (We take the order of the numbers into account.) 
Item 8. When three dice are rolled simultaneously:

1. Which of the following results is most likely?

- a 5 , a 2 , and a 3

- two $5 \mathrm{~s}$ and a 3

- three $5 \mathrm{~s}$

- The chances of obtaining each of these results are the same

2. Is one of these results less likely than the others? Which one?

Item 9. On a farm, there is a fishing pool. The owner wants to know how many fish there are in the pool. He took out 200 fish and marked each of them with a coloured sign. He released the marked fish back into the pool and let them get mixed in with the others. On the second day, he took out 250 fish in a random fashion and found that, among them, 25 were marked.

1. What is the approximate number of fish in the pool?

2. If owner randomly takes 100 more fish, approximately how many will be marked?

Item 10. A teacher asked Clara and Luisa to each toss a coin 150 times and to record whether the coin landed on heads or tails on each toss. For each "Heads," a 1 is recorded, and for each "Tails," a 0 is recorded. Here are the two sets of results:

$$
\begin{array}{r}
\text { Clara: } 01011001100101011011010001110001101101010110010001 \\
01010011100110101100101100101100100101110110011011 \\
01010010110010101100010011010110011101110101100011
\end{array}
$$

Luisa: 10011101111010011100100111001000111011111101010101

11100000010001010010000010001100010100000000011001
00000001111100001101010010010011111101001100011000

One girl followed the instructions, tossing the coin on each turn; the other girl cheated and just made the sequence up.

a. Which girl cheated?

b. How can you tell?

Item 11. In a certain town hospital, a record of the number of boys and girls born in the hospital is kept.

a. Which of these cases is more likely:

- There will be 8 or more boys among the next 10 babies born at the hospital

- There will be 80 or more boys among the next 100 babies born at the hospital

- Both results are equally likely

Explain your answer:

b. Which of these cases is more likely among the next 10 babies born at the hospital:

- There will be 7 or more boys

- There will be 3 or less boys

- The number of boys will be between 4 and 6

- $\quad$ These three results are equally likely

Explain your answer:

Item 12. A weather forecaster says that this year, there is a $70 \%$ chance of rain in Santiago de Compostela.

1. If this forecaster is right, how many rainy days would you expect this year in Santiago de Compostela?

2. Suppose that the forecaster said there was an $80 \%$ chance of rain this week and that it did not rain on Monday. What would you conclude about the statement that there was a $80 \%$ chance of rain?

3. If the prediction was $80 \%$ chance of rain, but it did not rain on Monday or Tuesday, what would you conclude? 


\section{Ortaokul Matematik Öğretmeni Adaylarının Olasılık Alan Bilgilerinin Olasılığın Farklı Anlamları Açısından İncelenmesi}

\section{Giriş}

Son yıllarda olasılık, matematik eğitiminde dikkate değer bir ilgiyi çekmekte, olasılık eğitimi ve öğretimine dair çalışmalar artmaktadır. Olasılığın uluslararası alanda gördüğü bu ilgi Türkiye'de matematik eğitimi programlarına ve öğretmen yetiştirme programlarına da yansımaktadır. 2013 yılında uygulanmaya başlanan ortaokul matematik öğretim programı olasılık konusunun ayrı bir öğrenme alanı olarak ele alındığı ilk program olmuştur (Milli Eğitim Bakanlığı [MEB], 2013). Fakat, son güncelleme ile yayınlanan yeni ortaokul matematik öğretim programında ise olasıllğa ayrılan sürenin azaltıldığı, olasılığın yalnızca klasik anlamının vurgulandığı ve önceden ortaokul programında yer alan birçok kazanımın (örneğin, bağımlı olayların olasılı̆̆ı) da lise düzeyine aktarıldığı görülmektedir. Olasılık öğrenme alanı yalnızca beş kazanımla 8. Sınıf düzeyinde, güncel ortaokul matematik programının yüzde 7'sini oluşturmaktadır (MEB, 2018). İlgili düzenlemenin Amerika'nın olasılık öğretimi çerçevesinde 1989, 2000 ve 2006 yıllarında yaptığı değişikliklere benzediği açıkça söylenebilir (Langrall, 2018). Langrall (2018) TIMMS 2015 kapsamında bulunan ülkelerin programlarını incelediğinde bu durumun (11 yaşın altındaki öğrencilere verilen olasıllk öğretimi) birçok ülkede geçerli olduğunu açıklamaktadır. Bu açıdan bir bakıma, olasılık konusunda daha derin kavramsal bilgiyi lise düzeyine bırakarak, öğretmen adaylarının teknolojiden destek alarak (simulasyonlar, vb.) olasılıkta daha çok kilit kavramların üzerine odaklanılması gerektiği fikrinin (Moore, 1997) şu anda uygulanan ortaokul öğretim programının içeriğine yansıdığı söylenebilir. Dünya genelinde ise olasılık öğretimi incelendiğinde basit olasılıksal düşünme becerilerinin okul öncesi düzeyden itibaren verilmesine rağmen, matematik öğretmen adaylarının ve hatta sınıf öğretmeni adaylarının üniversite eğitimleri süresince istatistik ve olasılık öğretimi özelinde ilgili eğitimleri yeterince aldıkları söylenemez (Batanero, Godino ve Roa, 2004).

Günümüz gelişen teknolojileri ve 21. yüzyıl ihtiyaçlarını dikkate aldığımızda olasılık öğretimine olan bakış açısının güncellenmesi gerektiği görülmektedir. Bütün bunların yanı sıra, olasılık öğretimi "olasılığın karakteristik özelliklerini, olasılığa farklı bakış açılarını (klasik, sıklıkçı, öznel ve aksiyomatik), yaygın kavram yanılgılarını, yanlış sezgileri de içermelidir" (Estrada, Batanero ve Díaz, 2018, s. 316). Olasılığa farklı yaklaşımlar, olasılıkta belirsizlik kavramıyla ilişkilidir ve diğer yaklaşımlara (Batanero, Chernoff, Engel, Lee ve Sánchez, 2016) nazaran temelde üç farklı bakış açısıyla değerlendirilebilir: öznel, klasik ve sıklıkçı yaklaşım (Hourigan ve Leavy, 2019). Olasılığın klasik yaklaşımı, 1980'lere kadar olasılığın oran yapısına odaklanan bir öğretimin ön planda olduğu ve teorik olasılığın ön plana çıkarıldığı yaklaşımdır. Bu yaklaşım ülkemizde ilkokul ve ortaokul matematik öğretim programı ele alındığında öne çıkan tek yaklaşımdır ve bağlamla ilişkilendirilerek verilebilecek örnek deneyleri de göz ardı etmiş olmaktadır. Sıklıkçı yaklaşıma göre ise, olasılık bir deney çok fazla sayıda tekrarlandığında olayın göreceli sıklıklarının limiti olarak tanımlanır ve aynı zamanda günümüz evrensel olasılık öğretiminde en etkin yaklaşımdır. Daha önceki öğretim programlarımızda deneysel olasılık olarak ortaokul düzeyinde ele alınmakta ve teorik olasılıkla ilişkilendirilmekteydi. Bu ilişkiye, MEB'in 2018 yılında yayınladığı ve uygulamaya geçirdiği ortaöğretim matematik öğretim programında 11 . sınıfta yer verilmektedir (MEB, 2018). Öznel yaklaşıma göre ise, olasılık bir inanışın kişisel derecelendirmesidir, yeni bir bilgi elde edildiğinde Bayes teoremiyle güncellenebilir ve bu yaklaşımın da ilköğretimde olasılık öğretiminde yer alabileceği öne sürülmüştür (Gómez-Torres, Batanero, Díaz ve Contreras, 2016). Olasilığın en temel bu üç farklı yaklaşımının olasılığı öğrenme ve öğretme üzerine çeşitli avantaj ya da dezavantajları olduğu bilinse de (Batanero, Henry ve Parzysz, 2005), olasıllk öğretiminde bu üç yaklaşıma da yer verilmeli ve bu yaklaşımlar arasındaki karşılaştırmalı ilişkilerden bahsedilmelidir (Koparan, 2019). Ortaokul matematik öğretimi programının güncel haliyle olasılık öğrenme alanı açısından yetersizliği olasılığın yalnızca klasik anlamını öne çıkaran öğretme biçiminden kaynaklanmaktadır. Bu bakış açısıyla, ortaokul matematik öğretmenlerinin üniversite eğitimleri sırasında olasıılık bilgilerinin geliştirilmesi onların olasılık öğretiminde sunacağı katkı için gereklidir. Matematik öğretimi ve olasılık ve istatistik öğretimi, bu iki alanın doğası gereği farklı olmalıdır (Batanero ve Diaz, 2012), ve bu farklılı̆ğ öğretmen adaylarının olasılık ve olasıllğın öğretimi konularında alacakları eğitimlerine yansıtmak ve olasılık ve istatistik anlayışlarını geliştirmek önemlidir (Jones ve Thornton, 2005; Stohl, 2005).

Diğer öğrenme alanlarında olduğu gibi, olasılık öğretmek için en temel olarak kabul gören öğretmenin ya da öğretmen adayının alan bilgisidir. Bu da olasıllğa dair iyi bir anlamaya sahip olmak ve sadece temel alan bilgisi değil ileri düzeyde alan bilgisi ve uzman düzey alan bilgisine de sahip olmak demektir (Ball, Thames ve Phelps, 2008). Temel alan bilgisi, (literatürde ortak veya yaygın alan bilgisi olarak da geçmektedir) matematik öğretmek için yeterli olmayan ama herhangi bir bağlamda gerekli olan temel matematik bilgisidir. Buna örnek olarak, çeşitli matematiksel sembollerin ve gösterimlerin bilinmesi, uygun kullanılması, matematiksel terminoloji bilgisi verilebilir. İleri düzeyde alan bilgisi, Ball ve arkadaşlarının (2008) yatay alan bilgisi ismiyle literatüre kazandırdığı, bu çalışmada, Gómez-Torres ve arkadaşlarının (2016) çalışmalarında olduğu gibi ileri düzeyde alan bilgisi olarak anılacaktır, bir öğretim programını öğretmek üzere ele alan öğretmenin bir kavramın bir 
seviyede öğretilmesinden önce (ve sonra), önceki (ve sonraki) seviyelerde bu kavramın hangi kavramlarla ilişkilendirebileceği hakkında bilgi sahibi olması demektir. Olasılık öğretimi için gereken öğretmenlik bilgisi açısından yaklaştığımızda, bu bilgi öğretmenlerin olasılığın farklı anlamları ve bu anlamlar arasındaki ilişkileri bilmesi anlamına gelir (Batanero ve ark., 2004). Gómez-Torres ve arkadaşları (2016) ileri düzeyde alan bilgisini ayrıca, öğrenciler ve alan hakkında bilinmesi gereken bilgiyi de kapsayacak şekilde ele almışlardır. Üçüncü olarak olasılık öğretmek için gereken olasılık alan bilgisi çerçevesinde ele alınabilecek alan bilgisi türü uzman düzey alan bilgisidir (Hill, Ball ve Schilling, 2008). Uzman düzey alan bilgisi, öğretmenin belirli bir matematiksel kavramı derinlemesine açıklayabilmesi, belirli öğretim yöntemleriyle verebilmesi, ilgili matematiksel fikirlerin temsil biçimlerini bilmesi ve açıklayabilmesi bilgisidir (Hill ve ark., 2008).

Öğretmenlerin ve öğretmen adaylarının olasılık alan bilgilerini veya olasılığa dair anlamalarını inceleyen çalı̧̧malar sınırlıdır (Gómez-Torres ve ark., 2016). Bu sınırlılığın en büyük sebeplerinden biri, olasılığın matematik öğretim programlarında diğer konulara görece daha az yer alıyor olması olabilir. Hourigan ve Leavy (2019)'e göre, yapılan çalışmalar çoğunlukla öğretmenlerin veya öğretmen adaylarının olasılık kavramlarına dair yaygın kavram yanılgıları, hataları, sezgisel yanılgıları (bias) veya öğrenme güçlüklerini inceleyen çalışmalardır. Batanero, Godino ve Cañizares (2005) ortaokul matematik öğretmen adaylarının sahip olduğu en temel üç olasılık kavram yanılgısının şunlar olduğunu tespit etmişlerdir: Temsil kısa yolu yanlılığı (representativeness bias), eş olasılık yanlılı̆̆ (equiprobability bias), sonuç yaklaşımı (outcome approach).

Öğretmenlerin ve öğretmen adaylarının olasılık alan bilgilerinin incelendiği çalışmalara göre, katılımcıların olasılık ve istatistik alanlarında diğer öğrenme alanlarına göre daha zayıf oldukları, olasılık anlayışlarının az olduğu ve bu öğrenme alanlarını öğretmeyi de diğerlerine göre daha zor buldukları gözlenmiştir (Shaughnessy, 1977; Stohl, 2005; Quinn, 1997). Bu nedenle de istatistik ve olasılık öğrenilmesi veya kavranması zor olan konulardan biri olarak görülmektedir (Olpak, Baltacı ve Arıcan, 2018; Stohl, 2005). Yalnızca öğretmek için gereken matematik alan bilgisi değil, öğretmenlerin ve öğretmen adaylarının istatistik ve olasıllğa tutumlarını inceleyen (örn. Estrada ve ark., 2018), olasillğa yönelik olarak pedagojik alan bilgilerini inceleyen (örn. Danişman ve Tanışlı, 2017), olasılık kavramlarında (örn. bağımlı olasılık, şans, örnek uzay) kavram yanılgılarını ve olasılığa yönelik inanışlarını inceleyen (örn. Bursalı ve Gökkurt-Özdemir, 2019; Stohl, 2005), ve olasılığa ilişkin kavramsal ve işlemsel bilgi düzeylerini inceleyen (örn. Ata, 2014; Karaaslan ve Ay, 2017; Kurt-Birel, 2017) çalışmalar yer almaktadır. Öğretmen adaylarının istatistik ve olasılığa yönelik anlayışlarını bilişsel düzeyde ölçmeye yönelik bir testi geliştirme araştırması da öğretmen adaylarının istatistiksel muhakeme becerilerini ölçen bir çalışmadır (Arican ve Kuzu, 2020). Arican ve Kuzu (2020)'nun da sonuçlandırdığı gibi öğretmen adaylarının istatistiksel çıkarımları yapmakta zorlandıkları ve temel olasılık kavramlarını anlama ve uygulamakta zorlandıkları tespit edilmiştir. Genel olarak, olasılı̆̆ın ortaokul matematik programındaki hacminin diğerlerine nazaran az olması ve zaman içinde yoğunluğun hafifletilmesi gibi sebeplerden ötürü öğretmenlerin ve öğretmen adaylarının olasılık alan bilgilerini inceleyen çalışmaların da benzer oranda az olduğu görülmektedir. Bu olasılığa verilen önemin de giderek azaldığını göstermektedir. Burada özetlenen çalışma ise, olasılığın farklı anlamlarına yönelik olarak ögretmen adaylarının olasılık alan bilgisinin farklı türlerine göre incelenmesi açısından önemlidir.

Öğretmen adaylarının olasılık alan bilgilerinin değerlendirilmesi ve katılabilecekleri olasılık derslerinin içeriğinin hazırlanması için çeşitli ölçme araçlarına ihtiyaç vardır. Bu çalışma, Gómez-Torres ve arkadaşları (2016)'nin ilkokul öğretmen adaylarının olasılık alan bilgilerini ölçmeye yönelik geliştirdikleri testin Türkçe'ye uyarlanmasını ve uyarlanan testin ortaokul matematik ögretmen adaylarının olasılık alan bilgilerinin incelenmesi amacıyla uygulanmasını içermektedir.

Dolayısıyla bu çalışmanın amacı, ortaokul matematik öğretmen adaylarının olasılık alan bilgilerini olasılı̆̆ın farklı anlamları üzerine ve matematik öğretmek için gereken bilgi çerçevesinde incelemektir. Bu amaçla, araştırmanın sorusu şu şekildedir: "Ortaokul matematik öğretmen adaylarının olasılığın farklı anlamlarına ve matematik öğretmek için gereken bilgiye göre, olasıllk alan bilgileri hangi düzeydedir?"

\section{Yöntem}

\subsection{Araștırmanın Modeli}

$\mathrm{Bu}$ araştırmada, ilköğretim matematik öğretmeni adaylarının matematik ve matematik öğretmeye yönelik kaygı düzeylerinin, bu kaygılar arasında anlamlı bir ilişki olup olmadı̆̆ının ve varsa matematik kaygısının matematik öğretme kaygısını yordayıp yormadığının belirlenmesi amaçlanmıştır. Bu amaçla araştırmanın modeli, betimleyici istatistiklerin yer aldığı tekil taramayı ve değişkenler arasındaki ilişkinin belirlenmesi amacıyla yapılan ilişkisel taramayı içine alan genel tarama modeli olarak seçilmiştir. Çünkü genel tarama modelleri, çok sayıda elemandan oluşan bir evrende, evren hakkında genel bir yargıya varmak amacı ile evrenin tümü ya da ondan alınacak bir örneklem üzerinde yapılan tarama düzenlemeleridir (Karasar, 2009). 


\section{2. Çalışma Grubu}

Araştırmada uygun durum örneklemesi kullanılmıştır. Uygun durum örneklemesinde araştırma yapılacak birey ya da grupların araştırma sürecine dâhil edilmesinin daha kolay ya da bunlara daha kolay ulaşılabilir olmasıyla ilgilidir (Ekiz, 2015). 2018-2019 eğitim-öğretim yılı güz döneminde araştırmacıların görev yapmakta olduğu İç Anadolu bölgesindeki iki ilin Eğitim Fakültesi matematik eğitimi anabilim dalında öğrenim görmekte olan toplam 378 öğretmen adayı ile yürütülmüştür. Ancak eksik ya da yanlış doldurulan ve uç değer temizliği nedeniyle çıkarılan veriler nedeniyle 307 öğretmen adayının verisi bu çalışmaya kaynaklık etmiştir. Buna göre 307 ögretmen adayının sınıf ve cinsiyet bazında dağılımı Tablo 1'de verilmiştir.

Tablo 1. Çalışma grubunun sınıf ve cinsiyet bazında dağılımı

\begin{tabular}{lcccccc}
\hline \multirow{2}{*}{ Sinıf } & \multicolumn{2}{c}{ Kiz } & Erkek & Toplam \\
\cline { 2 - 7 } & $\mathbf{N}$ & $\mathbf{\%}$ & $\mathbf{N}$ & $\mathbf{\%}$ & $\mathbf{N}$ & $\mathbf{\%}$ \\
\hline 1. Sinıf & 62 & 77 & 18 & 23 & 80 & 26 \\
\hline 2. Sinıf & 41 & 79 & 11 & 21 & 52 & 17 \\
\hline 3. Sinıf & 68 & 82 & 15 & 18 & 83 & 27 \\
\hline 4. Sinıf & $\mathbf{2 5}$ & 82 & 17 & 18 & 92 & 30 \\
\hline Toplam & $\mathbf{2 4 6}$ & $\mathbf{8 0}$ & $\mathbf{6 1}$ & $\mathbf{2 0}$ & $\mathbf{3 0 7}$ & $\mathbf{1 0 0}$ \\
\hline
\end{tabular}

Tablo 1 incelendiğinde çalışma grubunun cinsiyete göre; 246'sının kız (\%80) ve 61'inin erkek (\%20) ve sinıf düzeyine göre 80'inin 1. Sinıf (\%26), 52'sinin 2. sinıf (\%17), 82'sinin 3. Sinıf (\%27) ve 92'sinin 4. Sinıf (\%30) düzeyinde olduğu görülmektedir.

\subsection{Veri Toplama Araçları}

Araştırmada veriler "Öğretmen ve Öğretmen Adaylarına Yönelik Matematik Kaygı Ölçeği” ile "Matematik Öğretmeye Yönelik Kaygı Ölçeği'nden eş zamanlı olarak toplanmıştır.

Üldaş (2005) tarafından öğretmen ve öğretmen adaylarının matematiğe yönelik kaygı düzeylerini ortaya koyma amacıyla geliştirilen ölçek 4'lü likert tipinde olup 39 madde ve 7 boyuttan oluşmaktadır. Bu boyutlar sırasıyla matematik anlama kaygısı, matematik anlatma kaygısı, problem çözme kaygısı, aritmetik işlem kaygısı, matematiksel öz-yeterlik kaygısı, matematiksel yorumlama kaygısı ve matematiksel hata yapma kaygısı şeklindedir. Üldaş (2005), Ölçeğin güvenirlik çalışması için Cronbach Alpha katsayısını 0.95, ilgili araştırma için bu değer 0.88 olarak hesaplanmıştır. Ölçekten alınacak en düşük puan 39, en yüksek puan 156 puandır.

Araştırmada kullanılan bir diğer ölçek ise Matematik Öğretmeye Yönelik Kaygı Ölçeğidir. Bu ölçek Peker (2006) tarafından matematik ve sınıf öğretmen adaylarının matematik öğretmeye yönelik kaygı düzeylerinin belirlenmesi amacıyla geliştirilmiştir. Ölçek 5'li likert tipinde olup 4 boyut ve 23 maddeden oluşmaktadır. Bu boyutlar sırasıyla alan bilgisi kaynaklı kaygı, öz-güven kaynaklı kaygı, matematiği öğretmeye yönelik tutum kaynaklı kaygı ve alan eğitimi bilgisi kaynaklı kaygı şeklindedir. Peker (2006) ölçeğin Cronbach Alpha güvenirlik katsayısını 0.91, ilgili araştırma için bu değer aynı şekilde 0.91 olarak bulunmuştur. Ölçekten alınabilecek en yüksek puan 115 ve en düşük puan ise 23'tür.

Yine aynı şekilde ölçekten alınan puanın yüksek olması öğretmen adayının matematik öğretmeye yönelik kaygı düzeyinin yüksek olduğunu göstermektedir. Öğretmen ve Öğretmen Adaylarına Yönelik Matematik Kayg1 Ölçeğine ait maddelerin hepsi de olumlu iken Matematik Öğretmeye Yönelik Kaygı Ölçeğine ait maddelerin ilk 10 tanesi olumsuz, kalan 13 tanesi ise olumludur. Dolayısıyla veriler kodlanırken ters madde kodlaması yapılmıştır.

\subsection{Verilerin Analizi}

Öğretmen ve Öğretmen Adaylarına Yönelik Matematik Kaygı Ölçeği ile Matematik Öğretmeye Yönelik Kayg1 Ölçeği'nden elde edilen veriler SPSS 22 istatistik paket programı ile analize tabi tutulmuştur. Analize 378 veri ile başlanmış ancak ilk aşamada eksik, yanlış ve doldurulmayan 23 veri ölçekten çıkarılmıştır. Daha sonra verilerin normallik analizi için Mahallonobis uzaklık değerleri ve Box-Plot tekniği kullanılmış, 25 veri Mahallonobis uzaklığı ve 23 veri de uç değer olarak tespit edilmiştir. Böylelikle toplam 71 veri analizden çıkarılarak araştırmaya 307 veri ile devam edilmiştir. Geriye kalan verilere ait Kolmogorov-Simirnov anlamlılık (p) değerleri Matematik Kaygı Ölçeği için 0.64 ve Matematik Öğretmeye Yönelik Kaygı Ölçeği için ise 0.69 çıkmış ve bu değer $\mathrm{p}=0.05$ anlamlılık değerinden büyük olduğu için verilerin normal dağıldığı tespit edilmiştir. Dolayısıyla analizlerde parametrik testler kullanılmıştır.

İlköğretim matematik öğretmen adaylarının matematiğe yönelik kaygı düzeylerinin alt boyutlara göre durumunu belirlemek amacıyla ilk olarak ortalama ve standart sapma değerleri hesaplanmıştır. Ancak boyutlar arasında tespit edilen puan farklılığının yani kaygı durumları arasındaki farkın kıyaslanabilmesi ve bu farkın istatistiksel olarak anlamlı olup olmadığının tespit edilmesi için tekrarlı ölçümler için ANOVA testi uygulanmıştır. $\mathrm{Bu}$ testin varsayımlarından biri olan küresellik varsayımı sağlanmadığı için raporlamada 
Greenhouse and Geisser düzeltmesinden elde edilen F değeri kullanılmıştır. İlköğretim matematik öğretmeni adaylarının her iki kaygı ölçeğinden aldıkları puanların sınıf düzeyine göre farklılık gösterip göstermediğini belirlemek için parametrik test olan ANOVA testi kullanılmıştır. ANOVA testinin önemli koşullarından biri olan varyans homojenliği incelendiğinde "Levene Testi”nin her iki ölçeğin her alt boyutunda homojenlik şartını yerine getirdiği tespit edilmiştir. Araştırmanın bir diğer problemi olan matematik kaygısı ve matematik öğretme kaygısı arasındaki ilişkiyi tespit etmek için de Pearson Korelasyon analizi yapılmıştır. Son olarak ilköğretim matematik öğretmeni adaylarının matematik kaygılarının, matematik öğretmeye yönelik kaygılarını yordayıp yordamadığını belirlemek amacıyla Basit Doğrusal Regresyon analizi kullanılmıştır. Regresyon analizi öncesinde çoklu bağlantı problemine ilişkin analizler yapılmış ve herhangi bir çoklu bağlantı sorunu olmadığı belirlenmiştir.

Matematiğe yönelik kaygı ölçeğinden alınacak en düşük puan 1, en yüksek alınacak puan 5 'tir. Burada alınacak düşük puan düşük kaygıyı göstermektedir. Ölçek beşli likert tipinde olduğundan araştırmacılar tarafından beş düzey kullanımı tercih edilmiştir. Buna göre düzey aralıkları şu şekilde belirlenmiştir. 1.00-1.80 aras1 "kesinlikle katılmıyorum", 1.81-2.60 aras1 puan "katılmiyorum", 2.61-3.40 arası puan "kararsızım" ve 3.41-4.20 arası puan "katılıyorum" ve 4.20-5.00 aras1 "kesinlikle katılıyorum" şeklindedir. Matematik öğretmeye yönelik kaygı ölçeğinden en düşük alınacak puan 1 en yüksek alınacak puan 4'tür. Aynı şekilde bir önceki ölçekte olduğu gibi alınacak düşük puan düşük kaygıyı göstermektedir. Ayrıca ölçek dörtlü likert tipinde olduğundan araştırmacılar tarafından dört düzey kullanımı tercih edilmiştir. Buna göre düzey aralıkları şu şekilde belirlenmiştir. 1.00-1.75 arası "endişe duymam", 1.76-2.50 arası puan "az endişe duyarım", 2.51-3.25 arası puan "endişe duyarım” ve 3.26-4.00 arası puan "çok endişe duyarım” şeklindedir.

\section{Yöntem}

$\mathrm{Bu}$ çalışma, matematik öğretmen adaylarının olasılık alan bilgilerinin hangi düzeyde olduğunu incelemek üzere bir testin uyarlaması ve uygulanmasını içerdiği için bir tarama araştırmasıdır. Tarama araştırması, bir olgunun çeşitli değişkenler ya da faktörler uyarınca incelenmesi ve elde edilen bulguların bu değişkenlere göre analiz edilmesini içerir (Fraenkel ve Wallen, 2006; Karasar, 2005).

\subsection{Katılımcilar}

Çalışmaya Mersin Üniversitesi Eğitim Fakültesinde öğrenim görmekte olan 42'si 3. sınıf olmak üzere 3. ve 4. sınıf düzeyinde 98 ilköğretim matematik öğretmen adayı katılmıştır. Katılımcılar, ilköğretim matematik öğretmenliği güz ve bahar lisans programında yer alan 2 saati teorik 2 saati uygulamalı verilen istatistik ve olasılık derslerini almış olan öğrencilerden seçilmiştir. 2018-2019 akademik yılında Yüksek Öğretim Kurumu (YÖK) tarafından düzenlenen eğitim fakülteleri programlarında güz döneminde iki saatlik olasılık dersi ve bahar döneminde iki saatlik istatistik dersi bulunmaktadır ve öncekine göre saat sayısı yarıya düşürülmüştür. Ders içeriğinde değişiklik yapılmamıştır. İçerik genel olarak; sayma (kurallar, permütasyon, kombinasyon), olasılığa giriş, rasgele değişkenler ve dağılımları, kesikli ve sürekli olasılık dağılımları, veri analizi, güven aralıkları ve hipotez testleri, korelasyon, regresyon şeklindedir.

\subsection{Veri Toplama Araci}

Bu çalışmada, Gómez-Torres ve arkadaşları (2016)'nin hazırladığı testin Türkçe'ye uyarlanması üzerine çalışılmış ve ortaokul matematik öğretmeni adaylarına olasılık alan bilgilerini ölçmek üzere uygulanmıştır. Türkçe'ye çevrilerek katılımcılara uygulanan test açık uçlu sorulardan oluşmaktadır. Testi hazırlarken soru maddelerinin ön plana çıkardığı olasılığın farklı üç anlamı da dikkate alınmıştır (Batanero ve ark., 2005). Araştırma ekibi, çalışmalarının sonucu olarak 12 maddelik bir testi geliştirmiş, alan bilgisinin farklı bileşenleriyle ve olasılığın farklı anlamlarıyla beraber geçerli ve güvenilir bir biçimde olasılık alan bilgisini ölçtüğünü açıklamış (Cronbach alpha $=0,768$ ) ve öğretmen adaylarına uygulayarak onların olasılık alan bilgilerini de incelemişlerdir (Gómez-Torres ve ark., 2016). Testin Türkçe versiyonu için cronbach alpha değeri 0,82 olarak elde edilmiştir.

Bu test için seçilen 12 madde Azcárate (1995), Batanero, Garfield ve Serrano (1996), Chernoff (2011), Díaz ve Batanero (2009), Falk ve Wilkening (1998), Fischbein ve Gazit (1984), Green (1982, 1983) ve Shaughnessy ve Ciancetta (2002)'nın çalışmalarından alınan, İspanyolca'ya tercüme edilen ve uyarlanan, temel olasıllık kavramları dâhil, bağımlı-bağımsız olaylar, olasılığın tahmini, koşullu olasılık, örnekleme, eş olasılıklı olaylar, binom dağılımı gibi olasılık kavramlarını içermektedir. Testte yer alan soruların hangi alan bilgisi çeşidini değerlendirdiği ve olasılığın hangi yaklaşımını ön plana çıkardığı aşağıdaki tabloda gösterilmektedir. Testin tamamı, çalışmanın sonunda Ek 1'de yer almaktadır. 
Tablo 1. Test sorularının değerlendirdiği alan bilgisi türü ve olasılığın öne çıkan anlamı

\begin{tabular}{|c|c|c|}
\hline Temel Alan Bilgisi & Olasılığın anlamı & Soru numarast \\
\hline Olası sonuçların listelenmesi & Klasik & 1 \\
\hline Olasılıkların karşılaştırılması & Klasik & 2 \\
\hline Bileşik olasılık (çarpma kuralı): Bağımsız olaylar & Klasik & 3 \\
\hline Bileşik olasılık (çarpma kuralı): Bağımlı olaylar & Öznel & 4 \\
\hline Olasılığın tahmini & Sıklıkçı & 5 \\
\hline Adil oyun & Klasik & $6 \mathrm{a}$ \\
\hline \multicolumn{3}{|l|}{ İleri Düzeyde Alan Bilgisi } \\
\hline Beklenti & Klasik & $6 \mathrm{~b}$ \\
\hline Koşullu olasılik & Öznel & 7 \\
\hline Eşit olasılıklı olaylarda yanlılık & Klasik & 8 \\
\hline Örnekleme & Sıklıkçı & 9 \\
\hline Rasgeleliğin algılanması & Sıklıkçı/Öznel & 10 \\
\hline Temsil kisa yolu & Sıklıç̧/Öznel & $11 \mathrm{a}$ \\
\hline Binom dağılımı & Sıklıkçı/Öznel & $11 b$ \\
\hline Çıktı yaklaşımı: Tahmin & S1klıkçı & $12 \mathrm{a}$ \\
\hline Çıktı yaklaşımı: Tahmin geçerliliği & S1klıķı/Öznel & $12 \mathrm{~b}, \mathrm{c}$ \\
\hline Uzman Düzey Alan Bilgisi & & $\begin{array}{l}2,3,4,6 a, 10,11 \mathrm{a}, \\
11 \mathrm{~b}, 12 \mathrm{~b} \text { sorularında } \\
\text { tartışma bölümleri }\end{array}$ \\
\hline
\end{tabular}

Katılımcılara uygulanan test iki oturumda toplanmıştır, birinci oturum 2017-2018 Akademik Yılı'nda öğrenim gören ilköğretim matematik öğretmeni adayları 63 kişilik 3. ve 4. Sınıf öğrenci grubuyla yapılabilmiştir. Daha sonra örneklemin genişletilmesi karar alınmış ve bu nedenle, ikinci oturum, 2019-2020 Akademik Y1lı'nda öğrenim gören 4. Sınıf öğrencilerine de uygulanmıştır.

\subsection{Veri Analizi}

Testin uygulanması ile elde edilen veri, testi geliştiren Gómez-Torres ve arkadaşları (2016)'nin uyguladıkları biçimde puanlanmış ve testten alınabilecek maksimum puan bütün sorulara ve onların gerekçelerine doğru cevap verildiği takdirde 34'tür. Örneğin, Tablo 2'de görüldüğü gibi, ilk sorudan alınabilecek maksimum puan 3 'tür: 3 ve 4 elemanlı örnek uzayı listeleyebilme ve bunun için bir strateji geliştirebilme şeklinde alt soruların değeri birer puandır. Testte yer alan sorulardan bazıları, örneğin 11. soru, öğretmen adaylarının olasılığın hangi anlamını kullandıklarını ölçmektedir. Buna göre bu sorular için yapılan puanlamada buna da dikkat edilmiştir. Öğrenciler, örneğin 11. soru için temsil kısa yolu ve binom dağılımını kullanarak verecekleri cevapları olasılığın sıklıkçı ya da öznel anlamıla gerekçelendirebilirler. Yine bu soru için yapılan puanlamada, 11a ve 11b maddelerinin doğru cevaplanması halinde 1 er puan ve bu cevapların doğru gerekçeleri için de 1er puan verilerek toplam 4 puanla ölçülmüştür. Uzman düzey alan bilgisini ölçen test maddeleri, daha önceki test maddelerini cevaplarken katılımcıların sundukları gerekçelerin puanlanmasıyla ölçülmektedir. Örneğin, 6a maddesini cevaplayan öğrenci, oyunun adil olmadığını belirtir (temel düzey alan bilgisi) ve bu cevabı gerekçelendirir (uzman düzey alan bilgisi).

Bulgular özetlenirken testin iki özelliği ele alınmıştır: Olasılık alan bilgisi türü (temel düzeyde alan bilgisi, ileri düzeyde alan bilgisi ve uzman düzey alan bilgisi) ve olasılığın farklı anlamları (klasik anlamı, sıklıkçı anlamı ve öznel anlamı). Dolayısıyla bulgular öncelikle bu başlıklar altında detaylı incelenecek ve daha sonra genel olarak açıklanacaktır. Testte yer alan soruların madde güçlüğü ve madde ayırt edicilik indeksleri ücretsiz olan TAP (Test Analysis Program) ile hesaplanmıştır. Elde edilen sonuçlara göre test maddelerinin zorluk seviyelerinin $\% 3$ ile \%95 arasında seyrettiği ve farklı zorluk seviyelerinde birçok soru maddesinin olduğu ve cevap için gerekçe istenen maddelerde doğru cevap sayısının azaldığı söylenebilir. Aşağıda verilen Tablo 2'de her bir soru, sorunun açıklaması, hangi tip alan bilgisini ölçtüğü ve olasılığın hangi anlamını ön plana çıkardığı, madde güçlüğü ve madde ayırt edicilik indeks puanları görülmektedir. 
Tablo 2. Test maddelerinin madde güçlüğü ve madde ayırt edicilik indeksi puanları

\begin{tabular}{|c|c|c|c|c|c|}
\hline & $\begin{array}{c}\text { Olasılığın } \\
\text { Anlamı }\end{array}$ & Soru & Soru Açıklaması & $\begin{array}{l}\text { Madde } \\
\text { Güçlüğü }\end{array}$ & $\begin{array}{l}\text { Madde ayırt } \\
\text { edicilik indeksi }\end{array}$ \\
\hline \multirow{11}{*}{ 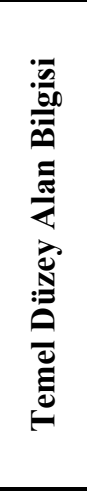 } & \multirow{5}{*}{ Klasik } & $1 \mathrm{a}$ & 3 elemanlı örnek uzayın sıralanması & 0,95 & 0,13 \\
\hline & & $1 b$ & 4 elemanlı örnek uzayın sıralanması & 0,92 & 0,21 \\
\hline & & $1 b$ & Strateji & 0,82 & 0,23 \\
\hline & & 2 & Olasılıkların karşılaştırılması & 0,82 & 0,26 \\
\hline & & 3 & Ortak olasılık. Bağımsız olaylar & 0,86 & 0,23 \\
\hline & \multirow{3}{*}{ Öznel } & $4 a$ & Bağımlı bileşik olaylar. En yüksek olasılık & 0,79 & 0,51 \\
\hline & & $4 \mathrm{~b}$ & Bağımlı bileşik olaylar. En düşük olasılık & 0,72 & 0,64 \\
\hline & & $4 \mathrm{c}$ & $4 \mathrm{a}$ ve $4 \mathrm{~b}$ cevapları arasındaki tutarlılık & 0,43 & 0,7 \\
\hline & \multirow{2}{*}{ Sıklıkçı } & $5 \mathrm{a}$ & Olasılık tahmin etme & 0,26 & 0,32 \\
\hline & & $5 \mathrm{~b}$ & Örneklem değgişebilirliği & 0,31 & 0,22 \\
\hline & Klasik & $6 a$ & Adil oyun & 0,93 & 0,08 \\
\hline \multirow{15}{*}{ 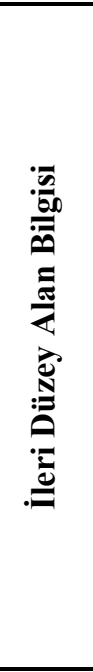 } & \multirow{2}{*}{ Klasik } & $6 b$ & Umut-Beklenti & 0,30 & 0,40 \\
\hline & & $6 b$ & Strateji & 0,29 & 0,4 \\
\hline & \multirow{2}{*}{ Öznel } & 7 & Koşullu olasılık & 0,57 & 0,51 \\
\hline & & 7 & Strateji & 0,50 & 0,57 \\
\hline & Klasik & 8 & Bağımsız bileşik olaylar, Eş olasılık yanlılığı & 0,01 & $-0,03$ \\
\hline & \multirow{4}{*}{ Sıklıkçı } & $9 \mathrm{a}$ & Örneklem büyüklüğünü tahmin etme & 0,40 & 0,8 \\
\hline & & $9 \mathrm{a}$ & Strateji & 0,38 & 0,77 \\
\hline & & $9 b$ & İkinci örneklemi tahmin etme & 0,34 & 0,67 \\
\hline & & $9 \mathrm{~b}$ & Strateji & 0,12 & 0,27 \\
\hline & \multirow{3}{*}{$\begin{array}{l}\text { Sıklıkçı/ } \\
\text { Öznel }\end{array}$} & 10 & Rastgeleliği anlama & 0,53 & 0,45 \\
\hline & & $11 \mathrm{a}$ & Örneklem büyüklüğünü dikkate almama & 0,11 & 0,23 \\
\hline & & $11 b$ & Binom dağılımı & 0,20 & 0,34 \\
\hline & Sıklıkçı & $12 \mathrm{a}$ & Ortalama tahmini & 0,57 & 0,41 \\
\hline & \multirow{2}{*}{$\begin{array}{l}\text { Sıklıkçı/ } \\
\text { Öznel } \\
\end{array}$} & $12 b$ & Bir çelişkili gözleme sahip tahminin geçerliliği & 0,45 & 0,6 \\
\hline & & $12 \mathrm{c}$ & İki çelişkili gözleme sahip tahminin geçerliliği & 0,28 & 0,47 \\
\hline \multirow{8}{*}{ 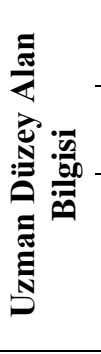 } & \multirow{2}{*}{ Klasik } & 2 & Olasılıkların karşılaştırılması - Gerekçe & 0,61 & 0,41 \\
\hline & & 3 & Ortak olasılık: Bağımsız olaylar - Gerekçe & 0,65 & 0,65 \\
\hline & \multirow{2}{*}{ Öznel } & 4 & Ortak olasılık: Bağımlı olaylar - Gerekçe & 0,41 & 0,6 \\
\hline & & $6 \mathrm{a}$ & Adil oyun - Gerekçe & 0,85 & 0,4 \\
\hline & \multirow{4}{*}{$\begin{array}{l}\text { Sıklıkçı/ } \\
\text { Öznel }\end{array}$} & 10 & Rasgeleliği algılama - Gerekçe & 0,40 & 0,42 \\
\hline & & $11 \mathrm{a}$ & Temsil kısa yolu - Gerekçe & 0,03 & 0,08 \\
\hline & & $11 b$ & Temsil kısa yolu: binom dağılımı - Gerekçe & 0,07 & 0,11 \\
\hline & & $12 b$ & Sonuç yaklaşımı - Gerekçe & 0,18 & 0,19 \\
\hline
\end{tabular}

\section{Bulgular}

Bulgular, ilköğretim matematik öğretmeni adaylarının olasılık alan bilgilerinin türlerine göre aşağıda özetlenmiştir: temel düzey alan bilgisi, ileri düzey alan bilgisi ve uzman düzey alan bilgisi. Her bir alt başlık altında alan bilgisi türü olasılığın klasik, sıklıkçı ve öznel anlamlarını sorgulayan soruların değerlendirmesi yer almaktadir.

\subsection{Temel Düzey Alan Bilgisinin İncelenmesi}

Bu alanda 11 soru maddesi bulunmaktadır ve en düşük ve en yüksek sonuçlar 0 ve 11 puandır. Bu kısımda 1 öğrenci en düşük puan olan 2 puan almıştır ve 5 öğrenci en yüksek puan olan 11 puan almayı başarmıştır. Puanların ortalaması 7,79 olarak elde edilmiştir. Bu bölümle ilgili elde edilen sonuçlar aşağıda Şekil 1'de yer alan grafik ve frekans tablosu ile verilmiştir. 


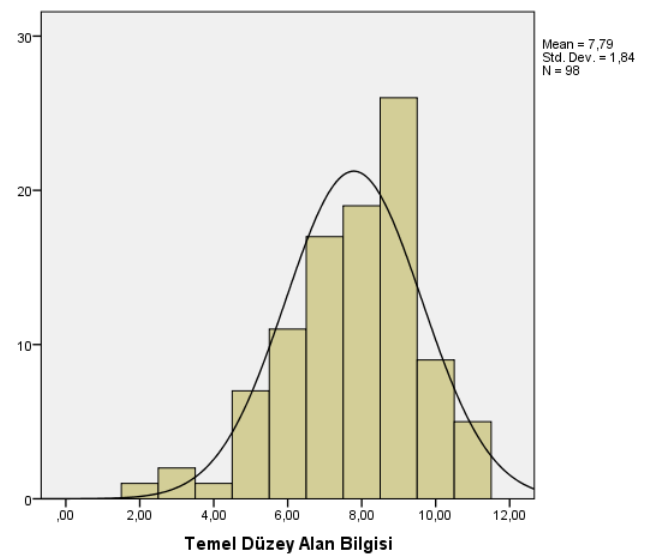

\begin{tabular}{|c|c|c|}
\hline Puan & Frekans & Yüzde \\
\hline 2,00 & 1 & 1,0 \\
\hline 3,00 & 2 & 2,0 \\
\hline 4,00 & 1 & 1,0 \\
\hline 5,00 & 7 & 7,1 \\
\hline 6,00 & 11 & 11,2 \\
\hline 7,00 & 17 & 17,3 \\
\hline 8,00 & 19 & 19,4 \\
\hline 9,00 & 26 & 26,5 \\
\hline 10,00 & 9 & 9,2 \\
\hline 11,00 & 5 & 5,1 \\
\hline Toplam & 98 & 100,0 \\
\hline \multicolumn{3}{|c}{} \\
\hline
\end{tabular}

Şekil 1. Katılımcıların temel düzey alan bilgisi puanlarını gösteren frekans dağılımı ve tablosu

Genel olarak olasılı̆̆ın klasik anlamına ilişsin temel düzey alan bilgisi 7,79 ortalama ile, Torres (2016)'de olduğu gibi kabul edilebilir düzeydedir. Öğrencilerin büyük çoğunluğu az sayıda elemana sahip örnek uzayın sıralanması, olasılıklar, bağımsız olaylar ve adil oyun ile ilgili soruları doğru cevaplandırmışlardır. Örnek uzayı listelemek için en çok kullanılan yöntem faktöriyel işlemi ve kutu yöntemi (birinci kutu birinci çekiliși, ikinci kutu ikinci çekilişi, vb.) olarak söylenebilir. Yalnızca az sayıda öğrenci 3 ve 4 elemanlı örnek uzayın çıktılarının sıralanması konusunda (sırasıyla 7 ve 10 öğrenci) çözüme ulaşmak için sistematik bir yaklaşım kullanmamıştır. İkinci sorunun çözümüne ulaşmak için öğrenciler durumu görsel kullanarak açılama yoluna giderek büyük oranda doğru cevap vermişlerdir (\%82), fakat iki farklı doğru cevap olmasına rağmen bunun ikisinden de bahseden olmamıştır. Katılımcılar arasında bu soruyu denklem kurarak ve x ve y şeklinde iki farklı bilinmeyen kullanarak çözmeye çalışanlar bulunmaktadır. Fakat, buldukları sonucu sonrasında yorumlamada da zorluk çektikleri söylenebilir. 6. soruda (6a) ise öğrenciler \%93 oranında oyunun adil olmadığını belirterek doğru cevaplamışlardır. Kısaca, öğrencilerin temel düzey alan bilgisi açısından olasılığın klasik anlamını kavramada ve uygulamada yeterince iyi oldukları söylenebilir.

Olasılı̆̆ın sıklıkçı anlamına ilişkin temel düzey alan bilgisi raptiye sorusu ile incelenmiştir. Bu maddede öğrencilerin sadece dörtte biri raptiyelerin duruş yönüne ilişkin yapılan deneyden bir olasıllık tahmini yapmışıtır. Doğal olarak deneyin tekrarı ile meydana gelecek olası sonuçlar yazma konusunda da doğru cevap oranı \%31'de kalmıştır. Birbiri ile çok tutarsız sonuçlar (soru 5b) veren öğrencilerin (\%26) yanı sıra ilk yapılan deneydeki olasılıkları göz önüne almadan raptiyelerin yukarı ve aşağı yönü gösterme durumlarının eşit olasıllğa sahip olduğunu düşünerek olası sonuç yazan (soru 5a) öğrenciler (\%31) de bulunmaktadır. Yanlış cevaplar arasında istenen olası tahminler arasında 50-50, 1-99, 90-10 gibi cevaplara da rastlanmıştır. Özetle, olasılığın sıklıkçı anlamına ilişkin temel düzey alan bilgisinin yeterli olmadığı görülmektedir.

Olasıllğın öznel anlamına ilişkin temel düzey alan bilgisi tuzaklı labirent sorusu (4a, 4b ve 4c) ile incelenmiştir. Öğrencilerin yarısından çoğu bağımlı olaylara ilişkin $4 \mathrm{a}$ ve $4 \mathrm{~b}$ maddelerine doğru cevap (sırasıyla $\% 79$ ve $\% 72$ oranında) vermişlerdir. Doğru cevaplar incelendiğinde tuzaklara giden her yol için olasılığı hesapladıkları ve her yol ayrımı için bu olasılıkları çarptıkları gözlenmiştir. Ancak bu maddelere verilen cevaplar karşılaştırıldığında tutarlılığın düşük olduğu gözlenmiş̧tir (\%43). Bazı öğrenciler herhangi bir olasılık hesaplamadan doğru cevabı verirken bir kısmı tuzaklara varana kadar karşılaşılan yol ayrımlarını gerekçe göstererek doğru cevabı vermişlerdir. Örneğin, seçenek (yol ayrımı) az olduğu için tuzaklara yakalanma olasılığının daha az olduğunu söylemişlerdir. Yine benzer şekilde, 5, 6, 7 ve 8 numaralı tuzaklara giden yolların, yol ayrımları daha doğrusal durduğu için gitme olasılığının fazla olduğunu iddia eden katılımcılar gözlenmiştir. Dolayısıyla, öğrencilerin temel düzeyde alan bilgisi kapsamında olasılı̆̆ın öznel anlamına yönelik eksikleri olduğu söylenebilir.

\section{2.İleri Düzeyde Alan Bilgisinin İncelenmesi}

Bu alanda 15 soru maddesi bulunmaktadır ve 0 ile 15 puan arasında puan alınmaktadır ve 3 öğrenci hiç doğru cevap verememiştir. 15 tam puan almayı başaran öğrenci yoktur. Aşağıda verilen Şekil 2'de öğrencilerin aldıkları puanlar ve frekansları açıkça görülmektedir. Ortalama puan 5,04 olarak elde edilmiştir. 


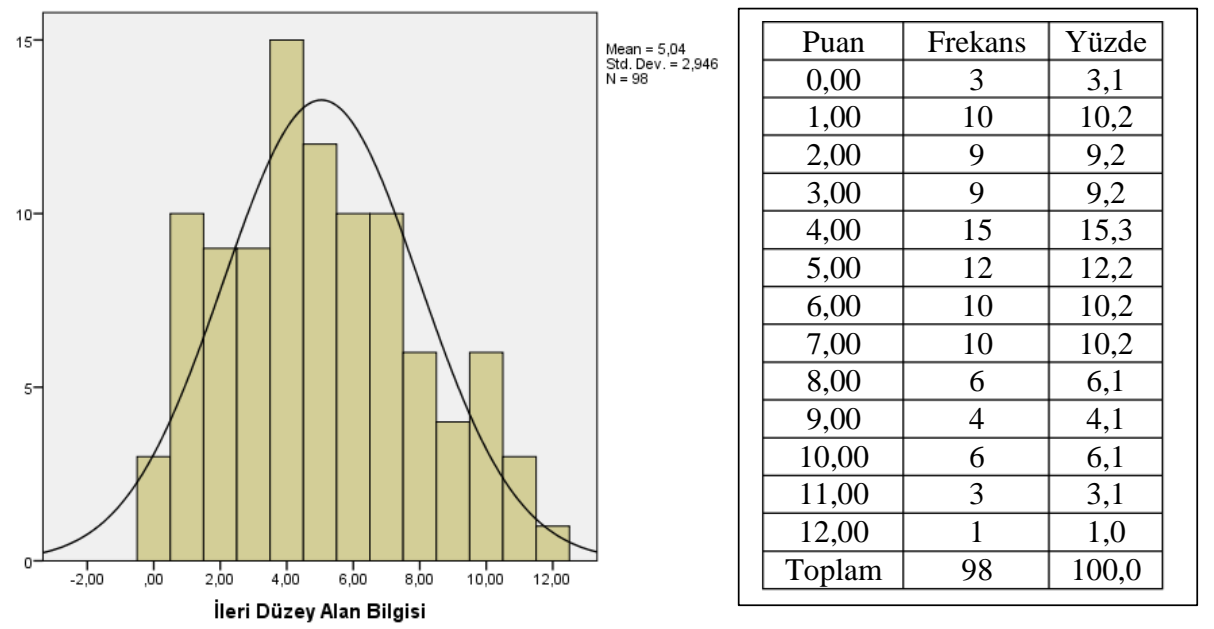

Şekil 2. Katılımcıların ileri düzey alan bilgisi puanlarını gösteren frekans dağılımı ve tablosu

Olasılığın klasik anlamına ilişkin ileri düzey alan bilgisi 6 ve 8. sorularla incelenmiştir. İki zarla oynanan bir oyunun adil olup olmadığını soran 6 . soruda, oyunun neden adil olmadığını gerekçesiyle birlikte açıklayabilen öğrenciler (\%29) azdır ve öğrencilerin sadece \%30’u oyunun adil bir oyuna dönüşmesi için oyuncuların ne kadar almaları gerektiğini belirleyebilmişlerdir. 3 zarın yuvarlanması ile ilgili olan 8 . soruda ise öğrencilerin yaklaşık yarısı soruyu boş bırakmış geriye kalanların ise hemen hemen tümü yanlış cevap vermişlerdir. En yüksek olasılığa sahip üçlüyü bulmaları istenen deneyde, öğrencilerin bu çıtıları sıralı üçlüler olarak algılaması ve dolayısıyla zarları da sıralamaları verilen yanlış cevapların sebebini açıklıyor olabilir. Sonuç olarak, öğrencilerin olasılığın klasik anlamına ilişkin ileri düzey alan bilgisi çok düşük düzeydedir ve geliştirilmesi gerekmektedir.

Olasılığın sıklıkçı anlamına ilişkin ileri düzey alan bilgisi 9-12. sorularla incelenmiştir. Balık sayısı tahmin etme ile ilgili olan soruda (9a) öğrenciler örneklem büyüklüğü tahmininde $\% 40$ oranında doğru cevap verebilmişlerdir. İkinci bir tahmin yapma konusunda (9b) doğru cevap verebilme oranı \%34 oranındadır. Ancak özellikle ikinci bir tahmin yapma konusunda öğrencilerin doğru bir akıl yürütme kullanmadıkları rasgele veya yanlış oranlarla tahmin yaptıkları gözlenmiştir. Buna göre öğrencilerin örneklem bilgilerinden hareketle evren büyüklüğünü tahmin etmede yeterli olmadıkları söylenebilir. Diğer sorularda da doğru cevap oranının orta seviyelerde veya altında olduğu görülmektedir. Örneğin 10. soruda öğrencilerin iki kişiden hangisinin rasgele sonuçlar elde ettiğini doğru cevaplama oranı \%53 ile yaklaşı orta düzeyde olduğu görülmektedir. Öğrencilerin bu soruya verdikleri yanlış cevaplar incelendiğinde, Barış'ın çok fazla 1 veya 0’1 yan yana yazmasından ötürü seriyi uydurduğu veya peş peşe ikililer halinde atışlar incelendiğinde Deniz'in serisinin daha gerçekçi olduğuna dair yorumlar yaptıkları görülmüştür. Benzer şekilde hava tahmini ile ilgili olan 12. soruda, öğrenciler yılın kaç günü yağış olacağını \%57 oranında doğru tahmin etmelerine karşın 1 ve 2 çelişkili durumlarda bu oranın sadece $\% 45$ ve \%28 ile orta düzeyin altında olduğu görülmektedir. Yanlış cevaplar incelendiğinde, tahminin iyi ya da kötü olduğunu yorumlamanın ötesinde, kaç günün yağışlı olabileceğine dair tahminlerde bulundukları gözlenmiştir.

Olasılığın öznel anlamına ilişkin ileri düzey alan bilgisinin genel olarak orta düzeyde olduğu söylenebilir. İki farklı renkteki zarın atıldığı deneyle ilgili olan 7 a sorusunda koşullu olasılığa ilişkin cevaplar \%57 oranında doğru olmakla beraber bunların büyük çoğunluğu (\%50) koşullu olasılık tanımına bağlı kalınarak verilmiştir. Deney sonucu istenen olası bütün çıktıları sıralayabilmelerine rağmen, olasılığı yanlış hesaplayan öğrenciler bulunmaktadır. Buna karşılık, hastanede doğan erkek bebeklerin olasılıklarının hesaplanması istenen 11. soruda öğrencilerin örneklem büyüklüğünden bağımsız olarak (11a) ve binom dağılımı yardımıyla (11b) çözüme ulaşma konusunda yetersiz oldukları (\%20) gözlenmiştir. Örneklem büyüklüğünü dikkate alarak, 10 ya da 100 doğum içinde, erkek bebek olması olasılığının eşit olmayacağını iddia eden öğrenciler \%11 oranındadır.

\subsection{Uzman Düzey Alan Bilgisinin İncelenmesi}

Uzman düzey alan bilgisi kapsamında olasılığın bütün anlamlarını içeren 8 soru maddesi bulunmakta ve 0 ile 8 puan arasında puan alınabilmektedir. Bütün bu soru maddeleri ilgili sorulara verilen cevapların gerekçelendirilmesi ile ilgili sorulardır. Bu gerekçelendirmeyi yapabilme ve verdikleri cevabı açıklayabilme öğrencilerin olasılık öğretimi için gerekli olan uzman düzey alan bilgisi konusunda yeterli olup olmadıkları konusunda fikir vermektedir. İki öğrenci hiç puan alamazken, tam puan alan öğrenci bulunmamaktadır. Aşağıda verilen Şekil.3'te öğrencilerin uzman düzey alan bilgisi türünden elde ettikleri puanların frekansları görülmektedir. Ortalama puan 3,20 olarak elde edilmiştir. 


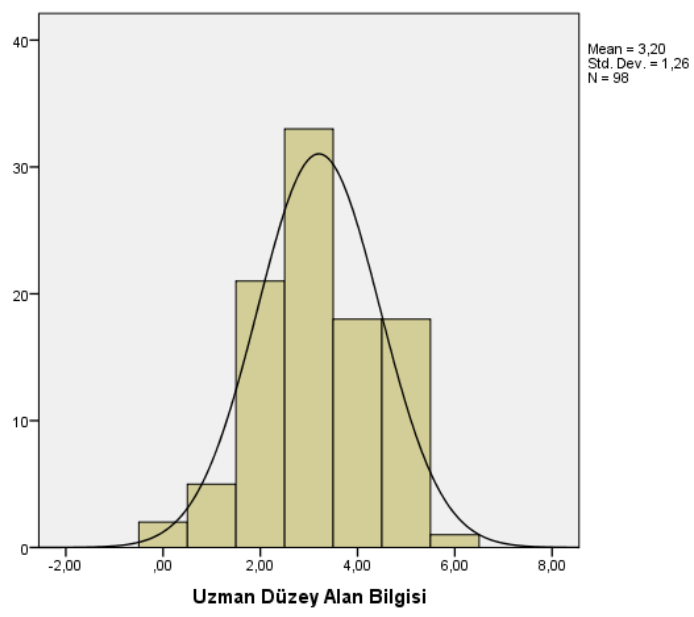

\begin{tabular}{|c|c|c|}
\hline Puan & Frekans & Yüzde \\
\hline 0,00 & 2 & 2,0 \\
\hline 1,00 & 5 & 5,1 \\
\hline 2,00 & 21 & 21,4 \\
\hline 3,00 & 33 & 33,7 \\
\hline 4,00 & 18 & 18,4 \\
\hline 5,00 & 18 & 18,4 \\
\hline 6,00 & 1 & 1,0 \\
\hline Toplam & 98 & 100,0 \\
\hline
\end{tabular}

Şekil 3. Katılımcıların uzman düzey alan bilgisi puanlarını gösteren frekans dağılımı ve tablosu

Olasılı̆̆ın klasik anlamına ilişkin uzman düzey alan bilgisi 2 ve 3 . sorularda verilen cevapların gerekçelendirilmesi ile incelenmiştir. Yüksek doğru cevap oranına sahip bu problemler, sırasıyla \%61 ve \%65 oranında anlaşılır bir çözüme ve gerekçelendirmeye sahiptir. Dolayısıyla, öğrencilerin olasılıkları karşılaştırma ve ortak olaylarda bağımsız deneyler konusunda yaptıkları gerekçelerinin yeterli olduğu ve konuyla ilgili anlamalarının iyi düzeyde olduğu söylenebilir.

Olasılığın sıklıkçı anlamına ilişkin katılımcıların uzman düzey alan bilgisi 10, 11a, 11b ve 12b maddeleri ile incelenmiş ve öğrencilerin çok zayıf düzeyde olduğu (sırasıla \%40, \%3, \%7 ve \%18) görülmüştür. Özetle, öğrenciler soruları doğru cevaplamış olsalar bile akılcı ve tutarlı gerekçeler gösterememişlerdir. Örneğin, 80-90 aralığı, 8-9 aralığından daha geniş olduğu için, hastanede doğan erkek bebek sayısının olasılığının hesaplanması konusunda öğrencilerin sezgisel olarak doğru cevabı hissettikleri gözlenmiştir. Fakat bu cevap örneklem büyüklüğü konusuyla ilişkilendirilmediği için doğru kabul edilmemiştir. Benzer şekilde $11 b$ maddesi için, öğrencilerin sezgisel olarak 11a’ya göre daha tutarlı cevaplar verdiği söylenebilir, fakat bu soruda da çoğunlukla binom dağılımından bağımsız gerekçeler sunulduğu için doğru kabul edilmemiştir.

Öznel olasılığın uzman düzey alan bilgisi bağlamında incelendiği sorular 4 ve 6 a maddeleridir. Özellikle 6a maddesindeki adil oyun sorusunda öğrencilerin akılcı ve doğru gerekçeler gösterme oranları \%85 oranında iyi seviyededir. Ancak bu yüksek seviyeye 4. soruda ulaşılamamıştır (\%41). Öğrencilerin tuzaklara yakalanma olasılıklarına ilişkin cevapları yüksek oranda doğru olsa da sundukları gerekçeler yeterince tutarlı ya da akılcı şekilde gözlenmemiştir. Burada bahsi geçen tutarsızlık, tuzağa yakalanma olasılığının en az olduğu ya da yüksek olduğu yolu açıklarken benzer gerekçeler sunmamış olmalarıdır.

\subsection{Genel bulgular}

Sorulardan alınacak puanlar 0 ile 34 arasındadır. 34 puan alabilmek için tüm cevap ve gerekçelerin doğru olması gerekir. Aşağıda verilen Şekil.4’te toplam puanlara yönelik katılımcıların aldıkları puanların frekans ve yüzde tablosu ve dağılımda da görüldüğü gibi öğrencilerden tam puan alan olmamıştır. En düşük puan 5 'tir ve en yüksek puan 26 olarak elde edilmiştir.
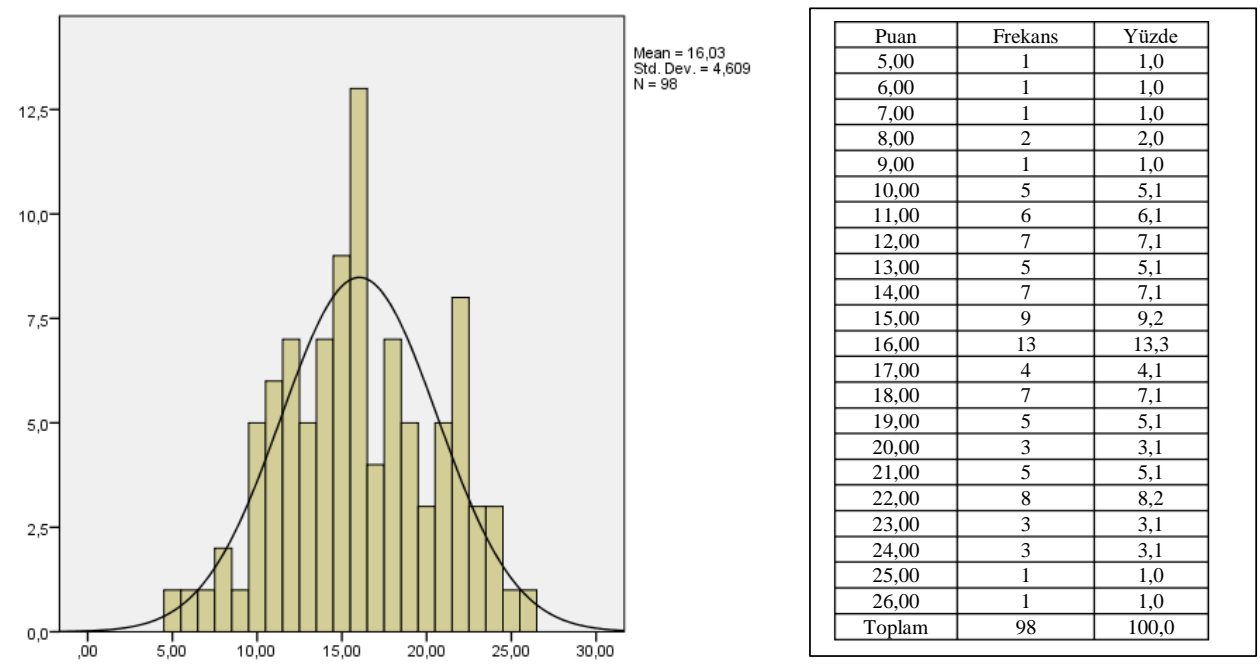

Şekil 4. Katılımcıların test sonuçlarını gösteren frekans dağılımı ve tablosu 
Alan bilgilerine ait kutu grafiği aşağıda Şekil 5'te verilmiştir. Temel düzey alan bilgisi ortalama puanının diğerlerinden daha iyi olduğu görülmektedir. Öğrencilerin geneli temel düzey alan bilgisi açısından kabul edilebilir düzeydedir. Sadece 3 katılımcı (2 ve 3 puan alanlar) diğerlerinden ayrılmaktadır ve kötü düzeydedir.

İleri düzey alan bilgisi puanları ise 0 ile 12 puan arasında geniş bir değişim aralığına sahip olmakla birlikte 15 tam puan alan öğrenci bulunmamaktadır. Maalesef 3 öğrenci sıfır puan alırken 10 öğrenci 1 puan alabilmiştir. Öğrencilerin bu düzeye ait alan bilgisi ortalaması 5 puan olup ortalamanın üzerinde puan alanların oranı $\% 40$ 'tır. Bu düzeydeki öğrenme alanlarına ilişkin iyileştirici çalışmalar yapılmalıdır.

En düşük ortalama puana sahip olan uzman düzey alan bilgisi 3 ortalama puana sahip olup öğrencilerin yaklaşık \%38'i ortalamanın üzerinde puan almıştır. Puanlar 0-6 arasında değişmekle birlikte 6 puan alan sadece 1 öğrenci bulunmaktadır. Sıfır puanlı 2, 1 puanlı 5 öğrenci vardır. Bu düzeyde madde güçlüğü verilerinde de görüldüğü gibi doğru cevap verme oranları 3 madde hariç kabul edilebilir seviyelerdedir. Ancak örneklem büyüklüğünü dikkate almama ve binom dağılımı ile ilgili 11a ve 11b maddelerinde doğru cevap oranı dramatik derecede düşüktür. Benzer şekilde $12 \mathrm{~b}$ maddesinde de düşük doğru cevap oranı gözlenmiştir.

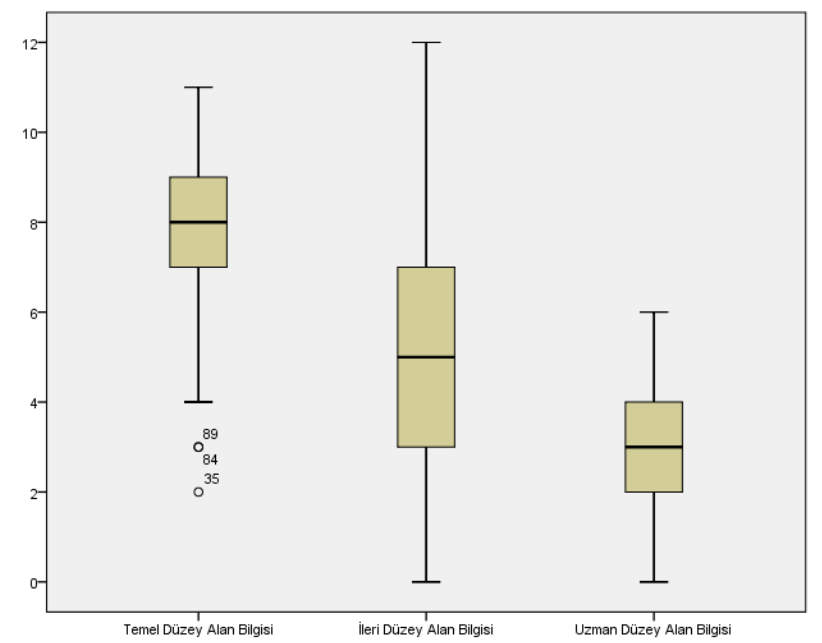

Şekil 5. Katılımcıların bilgi türlerine göre başarı düzeylerini gösteren kutu gösterimi

Aşağıda Şekil 6'da verilen grafikte katılımcıların olasılığın anlamı açısından puanlarının karşılaştırılması verilmiştir. Grafik incelendiğinde öğrencilerin klasik anlam açısından kabul edilebilir bir ortalamaya sahip olduğu söylenebilir. Sadece 2 öğrenci ortalamanın çok altında puan alabilmiştir. Buna karşılık sıklıkçı ve öznel anlamalar daha geniş bir değişim aralığına sahip olmakla beraber ortalama olarak da düşüktür. Olasılığın sıklıkçı anlamında 4 öğrenci diğerlerinden ayrılan daha yüksek puanlar üretmişlerdir.

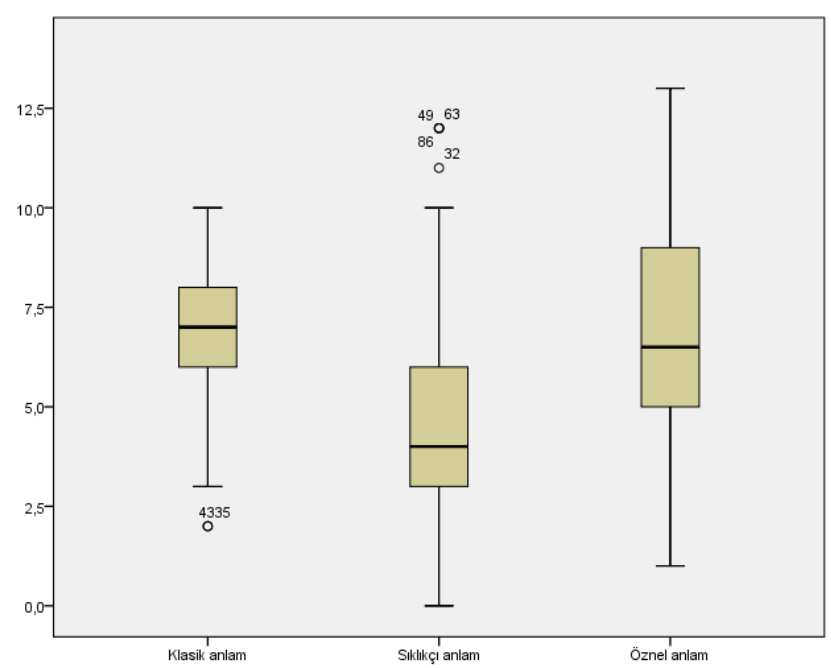

Şekil 6. Katılımcıların olasılığın anlamlarına göre puanlarını gösteren kutu gösterimi

\section{Tartışma ve Sonuç}

Türkçe’ye uyarlanan bu testin, ortaokul matematik öğretmen adaylarının olasılık alan bilgilerini yukarıda belirtilen iki farklı yönde (olasılığın anlamı ve alan bilgisi çeşidi) değerlendirmesi amaçlanmaktadır. Bu çalışmanın sonuçları öğretmen adayları için önerilebilecek olasılık konularının öğretimi gibi derslerin 
geliştirilmesinde ve tasarlanmasında, benzer şekilde istatistik ve olasıllk derslerinin içeriğinin gözden geçirilmesinde başvurulabilir bir bilgi kaynağı sunmaktadır.

Öğretmen adaylarının olasılık alan bilgilerinin hemen her düzeyde düşük seviyede olması, ortaokul matematik programında olasılığa yeterince önem verilmemesi, programda olasılık öğrenme alanının diğer öğrenme alanlarına göre yüzdesinin nispeten az olması, öğretmen adaylarının da olasılığın öğretimine ilgi duymamalarına veya önemsememelerine sebep oluyor olabilir. Bunlara ek olarak, öğretmen adaylarının inanışlarının da olasılık alan bilgilerinde etkili olduğunu iddia eden çalışmalar da bulunmaktadır (Danişman ve Tanışlı, 2017). Onların olasılığı daha derinlemesine öğrenme istemelerini engellemektedir. Diğer yandan, olasılığa yalnızca şans oyunlarının anlamını çözmek için başvurulması, matematik öğretmenleri de olasılığı matematiğin bir alt-kolu gibi algılamalarına ve öğretimlerinde de bu şekilde yansıtmalarına sebep olmuştur. Bütün bunlara rağmen, istatistiğe ilginin artması, olasılık kavramlarının da deneysel olarak verilmeye başlamasını sağlamıştır (Batanero ve ark., 2005). Günümüz sınav odaklı eğitim sistemi ve öğrencilerin sürekli olarak çoktan seçmeli sorulara maruz kalması olasılığın bu trendinin yakalanamamasına neden olmakta ve sadece öğrencilerin değil, öğretmenlerin de giderek olasıllğı ciddiye almamasına neden olabilir.

Öğrencilerin olasılık kavramları arasında ilişki kurabilmesini ve yeterli düzeyde bir anlayışa sahip olabilmeleri için olasılığın farklı anlamlarına yer verilen bir olasılık öğretimine ihtiyacımız bulunmaktadır. Ek olarak, olasılık kavramları arasında kurulması beklenen bu ilişkinin şans oyunlarından farklı ve çeşitli bağlamlarda da sunulması olasılı̆̆ı yalnızca öğrenciler için değil, öğretmenler için de anlamlı bir hale getirebilir (Koparan, 2019). Benzer şekilde, Koparan (2019), olasıllk öğretiminde simülasyon, oyun, etkinlik, materyal ve diğerlerine daha çok yer verilmesi gerektiğini de ortaya koymuştur. Bütün bu sonuçlar hem ortaokul/lise hem de lisans düzeyinde olasılığı öğretme yöntemlerini yeniden değerlendirmek gerektiğini göstermektedir.

$\mathrm{Bu}$ çalışmanın diğer bir sonucu ise, öğretmen adaylarının sezgisel olarak bildiklerini ileri ve uzman düzeyde açıklayamamış olmalarıdır. Bu sonuçla ilişkilendirilmek üzere, öğretmen adaylarının olasılık alan bilgilerinin işlemsel ve kavramsal bilgi bağlamında incelendiğinde de benzer sonuçlar ortaya koymasıdır (Ata, 2014; KurtBirel, 2017). Araştırmacı, öğretmen adaylarının olasılığın farklı anlamlarına (teorik, deneysel ve öznel anlamları) dair hem kavramsal hem de işlemsel anlayışlarının yetersiz olduğunu ve hatta bu ikisinin arasında pozitif yönde bir iliş̧i olduğunu ortaya koymuştur (Ata, 2014).

Çalışmamızın bulguları aynı zamanda, öğretmen adaylarının soruların çözümünde strateji sunamamalarını ya da sundukları stratejilerin farklılaşmadığını göstermektedir. Bu sonuç, öğretmen adaylarının olasıllk alan bilgilerinin ileri ve uzman düzeyde derin olmadığını, buldukları sonuçları açıklayamadıklarını, olasılığın farklı anlamlarına dair anlayışlarının kısıtlı ve dar bir düzeyde olduğunu göstermektedir.

Öğretmenlerin ya da öğretmen adaylarının en çok sorun yaşadığı olasılık kavram yanılgıları olarak temsil edilebilirlik yanlılığı (11), eş olasılık yanlılığı (8) ve sonuç yaklaşımını (12) inceleyen sorulara katılımcıların verdikleri cevapları incelediğimizde, en az puan alınan sorular olduğunu gözlemliyoruz. Buradan sonuçların, literatürde yer alan önceki bulgularla örtüştüğünü iddia edebiliriz (Bursalı ve Gökkurt-Özdemir, 2019; Hourigan ve Leavy, 2019; Stohl, 2005). Ek olarak, burada elde edilen bulgunun katılımcıların bu kavramlarla ilgili olarak ileri ve uzman düzeyde alan bilgilerinin oldukça yetersiz oldukları sonucuna da ulaşabiliriz. Özellikle eş olasılık yanlılığı ile ilgili soruda (8) başarı oranının 0.05 'in altında olması, bu sorunun katılımcılar tarafından çeviri nedeniyle anlaşılamamış olabileceğini de gösterebilir. Katılımcılarımızın temsil kısa yolu ile ilgili soru maddelerine (11a ve $11 \mathrm{~b})$ verdikleri cevapları incelediğimizde, çözüm için kullanmaları beklenen binom dağılımını kullanamadıkları veya bundan başka bir strateji geliştiremedikleri de onların hem ileri düzeyde hem de uzman düzeyinde olasılık alan bilgilerinin yetersiz olduğunu göstermektedir. Benzer şekilde, hava durumu ile ilgili soruya (12) verilen yanlış cevaplar incelendiğinde, katılımcıların sonuç yaklaşımı yanılgısına sahip olduğunu da iddia edebiliriz. Katılımcılar, ne kadar iyi bir tahmin olduğu hakkında yorum yapmak yerine, olayın kesinliğine dair karar vermeye çalışmışlardır.

Sonuç olarak, öğretmen adaylarının olasılık alan bilgilerinin, temel düzey, ileri düzey de uzman düzeyde olmak üzere yetersiz olduğunu, olasılığın farklı anlamlarına dair kısıtlı anlayışa sahip olduklarını söyleyebiliriz. Katılımcıların cevapları incelendiğinde ise, bulguların aynı zamanda literatürde önceden tespit edilmiş olan kavram yanılgılarını işaret ettiğini de iddia edebiliriz. Elde edilen bulgulara, olasılık ve istatistik kavramlarının yeterince ilişkilendirilmeden öğretiliyor olması (Hourigan ve Leavy, 2019) ve hatta ortaokul matematik öğretim programında da ayrı öğrenme alanları olarak yer alması, ortaokul matematik öğretmenlerinin ve öğretmen adaylarının olasılığa yeterince önem vermemesi, öğrencilerin ve dolayısıyla öğretmen adaylarının da çoktan seçmeli sınav sistemi çerçevesinde fazlasıyla ezberlemeye eğilimli olması olabilir.

\section{5. Öneriler}

Çalışmada elde edilen bulgulara göre, ortaokul matematik öğretimi ve öğretmen eğitimi açısından olasılı̆̆ın öğretimine dair bazı önerilerde bulunulabilir: Öncelikle, ortaokul matematik öğretim programında yer alan olasılık öğrenme alanı olasılığın farklı anlamlarını içerecek şekilde yeniden ele alınmalıdır. Bu aynı zamanda, 
öğretiminden sorumlu olan öğretmenlerin bu konular hakkında daha çok öğrenmelerini sağlayacaktır. Buna ek olarak, olasılık öğretimi, ilkokul ve ortaokul matematik öğretim programında daha çok yer almalı, daha erken seviyelerde öğretimine başlanmalıdır. İkinci öneri olarak, matematik öğretmen adaylarının üniversitede aldıkları olasılık ve ilişkili olarak istatistik derslerinin içeriği, olasılık ve istatistik kavramları ilişkilendirilerek ve olasılığın farklı anlamları ön plana çıkarılarak, yeniden gözden geçirilmelidir. Öğretmenlerin olasılık alan bilgilerinin her üç düzeyde de artırılması bu derslerin amaçlarından biri olarak belirlenmelidir. Bu anlamda, bu dersler olasılık öğretiminde yaşanabilecek kavram yanılgıları ve bunların nerelerden kaynaklanabileceğine dair bilgi vermelidir.

\section{Ek 1. Olasılık Alan Bilgisi Testi}

Ad1 Soyad1:

Sinif:

Aşağıdaki soruları yanıtlayınız.

\section{SORULAR}

1. Ali, Barış ve Cenk (kısaca A, B, C) isimli üç erkek çocuk sırayla bir video oyunu oynuyorlar. Bunun için sıraya girerek oyun sırasının kendilerine gelmesini beklemeleri gerekiyor. Bu oyunu oynayabilecekleri tüm olası sıralamayı yazmak istiyoruz: Örneğin sıralamalardan biri B-C-A'dır.

a. Farklı sıralanmaların tümünü yazın. Kaç farklı şekilde sıralanabilirler?

b. Dört erkek (A, B, C, D) oynamak istiyorsa kaç farklı sıralanma mümkün olur?

2. Deniz, bir torbanın içine 5 beyaz ve 7 siyah top koyuyor. Mustafa ise başka bir torbaya 3 beyaz ve 5 siyah top koyuyor. Eğer Deniz ve Mustafa'nın torbalarından siyah top çekme şanslarının eşit olmasını istiyorsak bir torbadan diğerine kaç tane siyah veya beyaz top aktarmamız gereklidir? Neden?

3. Yandaki ikili çarkıfelek bir karnaval oyununun bir parçasıdır. Bir oyuncu, çarkıfelekler durduğunda her iki ok da siyah bölümde duruyorsa oyunu kazanmaktadır.

a. Oyunu kazanma olasılığı nedir?

b. Neden?

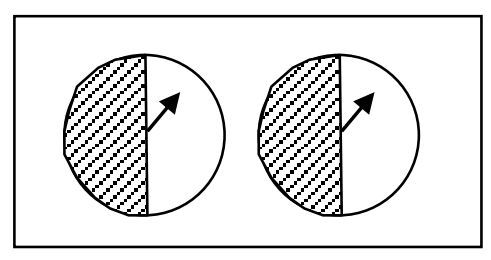

4. Bir robot şekildeki gibi bir labirente bırakılıyor. Labirentin 8 çıkışının her birinde şekildeki gibi numaralandırılmış birer tuzak vardır. Kavşaklardaki yollardan herhangi birini izleyerek ve girdiği yoldan da geri dönmemek kaydıyla;

a. Yakalanma olasılı̆̆ en yüksek olan tuzak veya tuzaklar hangileridir? Neden?

b. Yakalanma olasılığı en düşük olan tuzak veya tuzaklar hangileridir? Neden?

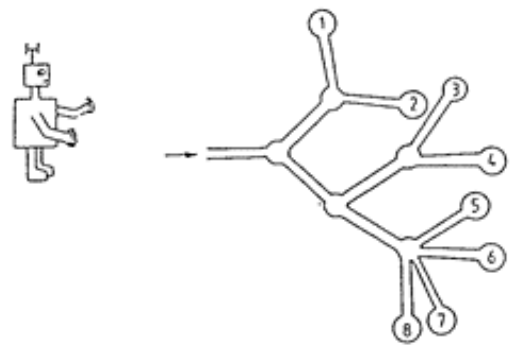

5. Bir kutudaki 100 raptiye öğretmen tarafindan masaya boşaltılıyor. Bunların 68 tanesinin uçları yukarıyı ve 32 tanesi de aşağıyı göstermiştir. Daha sonra öğretmen 4 öğrenciye (A, B, C, D) deneyi tekrarlamalarını söylüyor. Aşağıdaki tabloda her bir öğrencinin yaptı̆̆ı deneyin olası sonuçlarını yazınız.

\begin{tabular}{|l|l|l|l|l|}
\hline & Deniz & Mehmet & Duygu & Mustafa \\
\hline Yukarı & & & & \\
\hline Aşağ1 & & & & \\
\hline
\end{tabular}

6. Deniz ve Barış hilesiz iki zarla oynanan bir oyun oynuyorlar. Zarları yuvarlıyorlar ve üstte gelen yüzdeki sayıları çarpıyorlar. Eğer,

i. Çarpım çift sayı ise Deniz 1 Lira alıyor

ii. Çarpım tek sayı ise Barış 1 Lira alıyor

a. Oyun adil midir? Neden?

b. Eğer çarpım sonucu çift sayı olduğunda Deniz 1 Lira alıyorsa, oyunun adil olabilmesi için, çarpım sonucu tek sayı olduğunda Barış kaç Lira almalıdır? 
7. Biri sarı diğeri mavi iki hilesiz zar atılıyor. Üstlerinde gelen noktaların çarpımı 12 elde ediliyor. Zarlardan birinin 6 gelmesi olasılığı nedir? (Sayıların sırası göz önüne alınmaktadır.)

8. 3 zar aynı anda atılıyor. Sonuçlar (a, b, c) şeklinde sıralı üçlü olarak kaydediliyor.

a. Aşağıdaki sonuçlardan elde edilme olasılığı en yüksek olan hangisidir?

i. $(5,2,3) \ldots \ldots \ldots$

ii. $(5,5,3) \ldots \ldots \ldots$

iii. $(5,5,5) \ldots \ldots \ldots$

iv. Bu sonuçların her birinin elde edilme şansı eşittir

b. Bu sonuçlardan herhangi biri diğerlerinden daha az olasılığa sahip midir? Hangisi?

9. Bir balık çiftliğinin sahibi havuzdaki balıkların sayısını öğrenmek istiyor. Havuzdan 200 balık çıkararak bunları işaretliyor ve tekrar diğer balıkların arasına bırakıyor. Sonraki gün 250 balığı havuzdan çıkarıyor ve 25 tanesinin işaretlenmiş balıklar olduğunu görüyor.

a. Havuzdaki balık sayısı yaklaşık olarak nedir?

b. Eğer havuzdan rasgele 100 balık daha çıkarılırsa yaklaşık kaç tanesi işaretli olur?

10. Bir öğretmen 2 öğrencisine (Deniz ve Barış) düzgün bir parayı $150 \mathrm{kez}$ atmalarını ve tura gelirse 1, yazı gelirse 0 ile kaydetmelerini istiyor. Aşağıdaki sonuçlar elde ediliyor. Öğrencilerden biri talimatlara uygun şekilde parayı atarak kayıt oluşturmuş ancak diğeri talimatlara uymamış, hile yaparak sadece bir sayı serisi yazmıştır.

a. Hile yapan hangi öğrencidir?

b. Bunu nasıl söyleyebiliyorsunuz?

Deniz: 01011001100101011011010001110001101101010110010001010100111001101011001011 0010110010010111011001101101010010110010101100010011010110011101110101100011

\section{Barıș: 1001110111101001110010011100100011101111110101010111100000010001010010000 01000110001010000000001100100000001111100001101010010010011111101001100011000}

11. Bir şehir hastanesinde doğan erkek ve kız çocuklarının kaydı tutulmaktadır. Buna göre;

a. Aşağıdakilerden hangisinin olasılığı daha yüksektir? Açıklayınız.

i. Son doğan 10 bebeğin 8 veya daha fazlası erkek olacaktır.

ii. Son doğan 100 bebeğin 80 veya daha fazlası erkek olacaktır.

iii. Yukarıdaki iki sonuç da eşit olasılıklıdır.

b. Son doğan 10 bebek için aşağıdakilerden hangisi en yüksek olasılığa sahiptir? Açıklayınız.

i. 7 veya daha fazla erkek bebek doğacaktır.

ii. 3 veya daha az erkek bebek doğacaktır

iii. Erkek bebek sayısı 4 ile 6 arasında olacaktır.

iv. Yukarıdaki 3 sonuç da eşit olasılıklıdır.

12. Bir meteoroloji uzmanı bu yıl Adana'da yağmur ihtimalinin $\% 70$ olduğunu söylemektedir.

a. Eğer tahmini doğru ise, bu yıl Adana'da kaç günün yağmurlu olmasını beklersiniz?

b. Meteoroloji uzmanının bu hafta yağmur yağma olasılığının $\% 80$ olduğunu söylediğini ve Pazartesi günü de yağmur yağmadığını düşünelim. \%80 yağmurlu olması tahmini hakkında ne düşünürsünüz?

c. Eğer yağmur olasılığ $1 \% 80$ ise, ama Pazartesi veya Salı yağmur yağmadıysa nasıl bir sonuç çıkarırsınız?

\section{Kaynaklar / References}

Arican, M., \& Kuzu, O. (2020). Diagnosing preservice teachers' understanding of statistics and probability: Developing a test for cognitive assessment. International Journal of Science and Mathematics Education, 18, 771-790.

Ata, A. (2014). Öğretmen adaylarının olasılık konusuna ilişkin kavramsal ve işlemsel bilgi düzeylerinin incelenmesi (Yayımlanmamış yüksek lisans tezi). Eskişehir Osmangazi Üniversitesi, Eğitim Bilimleri Enstitüsü, Eskişehir. 
Azcárate, P. (1995). El conocimiento profesional de los profesores sobre las nociones de aleatoriedad y probabilidad. (Unpublished doctoral dissertation). University of Cádiz, Spain.

Ball, D. L., Thames, M. H., \& Phelps, G. (2008). Content knowledge for teaching. What makes it special? Journal of Teacher Education, 59(5), 389-407.

Batanero, C., Chernoff, E. J., Engel, J., Lee, H. S., \& Sánchez, E. (2016). ICME-13 Topical Surveys: Research on teaching and learning probability. Springer, Cham.

Batanero, C., \& Díaz, C. (2012). Training school teachers to teach probability: Reflections and challenges. Chilean Journal of Statistics, 3(1), 3-13.

Batanero, C., Garfield, J. B., \& Serrano, L. (1996). Heuristics and biases in secondary school students' reasoning about probability. In L. Puig \& A. Gutiérrez (Eds.), Proceedings of the Twentieth Conference of the International Group for the Psychology of Mathematics Education (Vol. 2, pp. 51-59). Valencia, Spain: IGPME.

Batanero, C., Godino, J. D., \& Roa, R. (2004). Training teachers to teach probability. Journal of Statistics Education, 12(1).

Batanero, C., Godino, J. D., \& Cañizares, M. J. (2005). Simulation as a tool to train pre-service school teachers. In J. Adler (Ed.), Proceedings of first ICMI African regional conference. Johannesburg: First Africa Regional Congress of ICMI on Mathematical Education (AFRICME-1). Witwatersrand University, Johannesburg, South Africa.

Batanero, C., Henry, M., \& Parzysz, B. (2005). The nature of chance and probability. In G. Jones (Ed.), Exploring probability in school: Challenges for teaching and learning (pp. 15-37). New York: Springer.

Bursalı, G. G., \& Gökkurt-Özdemir, B. (2019). Instructional explanations of mathematics teachers and preservice teachers on misconceptions: The subject of probability. Journal of Computer and Education Research, 7(14), 642-672. DOI: 10.18009/jcer.639384

Chernoff, E. J. (2011). Investigating relative likelihood comparisons of multinomial, contextual sequences. In M. Pytlak, T. Rowland, \& E. Swoboda (Eds), Proceedings of the Seventh Conference of the European Society for Research in Mathematics Education (591-600). Rzeszow: European Society for Research in Mathematics Education (ERME).

Danişman, Ş., \& Tanışlı, D. (2017). Examination of mathematics teachers’ pedagogical content knowledge of probability. Malaysian Online Journal of Educational Sciences, 5(2), 16-34.

Díaz, C., \& Batanero, C. (2009). University students' knowledge and biases in conditional probability reasoning. International Electronic Journal of Mathematics Education, 4(3), 131-162.

Estrada, A., Batanero, C., \& Díaz, C. (2018). Exploring teachers' attitudes towards probability and its teaching. In C. Batanero, E. J. Chernoff (Eds), Teaching and Learning Stochastics: Advances in Probability Education Research (pp. 313-332). Cham, Switzerland: Springer International Publishing.

Falk, R., \& Wilkening, F. (1998). Children's construction of fair chances: Adjusting probabilities. Developmental Psychology, 34(6), 1340-1357.

Fischbein, E., \& Gazit, A. (1984). Does the teaching of probability improve probabilistic intuitions? Educational Studies in Mathematics, 15(1), 1-24.

Fraenkel, J. R., \& Wallen, N. E. (2006). How to design and evaluate research in education (6th ed.). New York: McGraw-Hill.

Gómez-Torres, E., Batanero, C., Díaz, C., \& Contreras, J. M. (2016). Developing a questionnaire to assess the probability content knowledge of prospective primary school teachers. Statistics Education Research Journal, 15(2), 197-215.

Green, D. R. (1982). Probability concepts in school pupils aged 11-16 years. (Unpublished Doctoral Dissertation) The Loughborough University of Technology, The United Kingdom.

Green, D. R. (1983). From thumbtacks to inference. School Science and Mathematics, 83(7), 541-551.

Hill, H. C., Ball, D. L., \& Schilling, S. G. (2008). Unpacking pedagogical content knowledge: Conceptualizing and measuring teachers' topic-specific knowledge of students. Journal for Research in Mathematics Education, 39(4), 372-400.

Hourigan, M., \& Leavy, A. M. (2019). Pre-service teachers' understanding of probabilistic fairness: Analysis of decisions around task design. International Journal of Mathematical Education in Science and Technology, $1-23$.

Jones, G. A., \& Thornton, C.A. (2005). An overview of research into the teaching and learning of probability. In G. A. Jones (Ed.) Exploring Probability in School (pp. 65-92). Boston: Springer US.

Karaaslan, K. G. ve Ay, Z. S. (2017). Öğretmen adaylarının olasılık konusuna ilişkin alan bilgilerinin kavramsalişlemsel bilgi kapsamında incelenmesi. Abant İzzet Baysal Üniversitesi Ĕ̆itim Fakültesi Dergisi, 17(2), 716736.

Karasar, N. (2005). Bilimsel araştırma yöntemi. (15. Baskı). Ankara: Nobel Yayın Dağıtım.

Koparan, T. (2019). Teaching game and simulation-based probability. International Journal of Assessment Tools in Education, 6(2), 235-258. 
Kurt-Birel, G. (2017). The investigation of pre-service elementary mathematics teachers' subject matter knowledge about probability. Mersin Üniversitesi Ĕgitim Fakültesi Dergisi, 13(1), 348-362.

Langrall, C. W. (2018). The status of probability in the elementary and lower secondary school mathematics curriculum: The rise and fall of probability in school mathematics in the United States. In C. Batanero, E. J. Chernoff (Eds), Teaching and Learning Stochastics: Advances in Probability Education Research (pp. 3950). Cham, Switzerland: Springer International Publishing.

Shaughnessy, J. M., \& Ciancetta, M. (2002). Students' understanding of variability in a probability environment. In B. Phillips (Ed.), Proceedings of the Sixth International Conference on the Teaching of Statistics, Cape Town, South Africa. [CD-ROM] Voorburg, The Netherlands: International Statistical Institute. Retrieved from: https://iase-web.org/documents/papers/icots6/6a6_shau.pdf?1402524962

Millî Eğitim Bakanlığı [MEB]. (2013). Ortaokul Matematik Dersi (5, 6, 7 ve 8. Sinıflar) Öğretim Programı. Ankara: MEB Yayınları.

Millı̂ Eğitim Bakanlı̆̆ı [MEB]. (2018). Ortaöğretim Matematik Dersi (9, 10, 11 ve 12. Stnıflar) Öğretim Programı. Ankara: MEB Yayınları.

Moore, D. S. (1997). New pedagogy and new content: The case of statistics. International Statistical Review, 65(2), 123-137.

Olpak, Y. Z., Baltaci, S., \& Arican, M. (2018). Investigating the effects of peer instruction on pre-service mathematics teachers' achievements in statistics and probability. Education and Information Technologies, 23(6), 2323-2340.

Quinn, R. J. (1997). Effects of mathematics methods courses on the mathematical attitudes and content knowledge of preservice teachers. The Journal of Educational Research, 91(2), 108-114.

Shaughnessy, J. M. (1977). Misconceptions of probability: An experiment with a small-group, activity-based, model building approach to introductory probability at the college level. Educational Studies in Mathematics, $8,285-316$.

Stohl, H. (2005). Probability in teacher education and development. In G. A. Jones (Ed.), Exploring probability in school: Challenges for teaching and learning (pp. 345-366). New York: Springer. 